\title{
The effect of rainfall amount and timing on annual transpiration in a grazed savanna grassland
}

Matti Räsänen ${ }^{1}$, Mika Aurela ${ }^{2}$, Ville Vakkari ${ }^{2,3}$, Johan P. Beukes ${ }^{3}$, Juha-Pekka Tuovinen ${ }^{2}$, Pieter G. Van $\mathrm{Zyl}^{3}$, Miroslav Josipovic ${ }^{3}$, Stefan J. Siebert ${ }^{4}$, Tuomas Laurila ${ }^{2}$, Markku Kulmala ${ }^{1}$, Lauri Laakso ${ }^{2,3}$, Janne 5 Rinne $^{5}$, Ram Oren ${ }^{6,7,8}$, and Gabriel Katul ${ }^{6,8}$

${ }^{1}$ Institute for Atmospheric and Earth System Research, University of Helsinki, Finland

${ }^{2}$ Finnish Meteorological Institute, Helsinki, Finland

${ }^{3}$ Atmospheric Chemistry Research Group, Chemical Resource Beneficiation, North-West University, Potchefstroom, South

10 Africa

${ }^{4}$ Unit for Environmental Sciences and Management, North-West University, Potchefstroom, South Africa

${ }^{5}$ Department of Physical Geography and Ecosystem Science, Lund University, Sweden

${ }^{6}$ Nicholas School of the Environment, Duke University, Durham, North Carolina, USA

${ }^{7}$ Department of Forest Science, University of Helsinki, Finland

$15{ }^{8}$ Department of Civil and Environmental Engineering, Duke University, Durham, North Carolina, USA

Correspondence to: Matti Räsänen (matti.rasanen@helsinki.fi)

\section{Abstract}

The role of precipitation $(P)$ variability on evapotranspiration (ET) and its two components, transpiration $(T)$ and evaporation

(E) from savannas, continues to draw significant research interest given its relevance to a number of eco-hydrological applications. Our study reports on six years of measured ET and estimated $T$ and $E$ from a grazed savanna grassland in Welgegund, South Africa. Annual $P$ varied significantly in amount (508 to $672 \mathrm{~mm} \mathrm{yr}^{-1}$ ), with dry years characterized by infrequent early-season rainfall. $T$ was determined using annual water-use efficiency and gross primary production estimates derived from eddy covariance measurements of latent heat flux and net ecosystem $\mathrm{CO}_{2}$ exchange rates. The computed annual

$25 T$ was nearly constant, $331 \pm 11 \mathrm{~mm} \mathrm{yr}^{-1}(T / \mathrm{ET}=0.52)$, for the four wet years with frequent early wet-season rainfall, whereas annual $T$ was 268 and $175 \mathrm{~mm} \mathrm{yr}^{-1}$ during the dry years. Annual T/ET was linearly related to the early wet-season storm frequency. The constancy of annual $T$ during wet years is explained by the moderate water stress of $\mathrm{C}_{4}$ grass and constant annual tree transpiration covering $15 \%$ of the landscape. However, grass transpiration declines during dry spells. Moreover, grasses respond to water availability with a dieback-regrowth pattern, reducing leaf area and transpiration during drought.

These changes lead to an anomalous monthly T/ET relation to leaf-area index (LAI). The results highlight the role of the $\mathrm{C}_{4}$ grass layer in the hydrological balance and suggest that the grass response to dry spells and drought is reasonably described by precipitation timing. 


\section{Introduction}

Similar to other semi-arid areas, wooded grasslands in central South Africa deliver essential ecosystem services such as grazing land and fodder (Bengtsson et al., 2019). In such semi-arid zones, evapotranspiration (ET) approximately matches annual precipitation $\left(P \approx 500 \mathrm{~mm} \mathrm{yr}^{-1}\right.$; Zhang et al., 2001). The transpiration $(T)$ component accounts for water loss from the leaf stomata of the sparse tree component, seasonal grasses, and the minor forb component. The evaporation $(E)$ component is large following rain events, as intercepted water and near-surface soil water evaporate; the latter may continue over periods longer than a week (Perez-Priego et al., 2018). The partition of ET between $E$ and $T$ may affect the net radiation $\left(R_{n}\right)$ and surface temperature on short timescales (sub-daily). However, the processes that increase the proportion (and amount) of water used in $T$, facilitating greater carbon uptake and subsequent fodder production for cattle, occur over timescales of weeks or longer. Given the link between $T$ and carbon uptake from the atmosphere, there is growing interest in how ET is partitioned into $E$ and $T$ in semi-arid ecosystems (Merbold et al., 2009; Sankaran et al., 2004; Scanlon et al., 2002, 2005; Scholes and Archer, 1997; Volder et al., 2013; Williams and Albertson, 2004; Xu et al., 2015; Yu and D'Odorico, 2015). The aim here is to explore this partition of ET using a long-term data set of measured fluxes of energy, water, carbon dioxide $\left(\mathrm{CO}_{2}\right)$, and vegetation activity from a grazed wooded grassland. The focus is restricted to processes operating over timescales ranging

15 between daily and seasonal, commensurate with controls over the annual partition of $P$ into $T$, and the resulting carbon uptake in gross primary production (GPP). These longer timescales are of interest in the valuation of ecosystem productivity and their services when assessing climatic shifts (Godde et al., 2020). The results presented here on the partitioning of ET must be viewed as necessary but insufficient for developing best practices for the management of grazing or fodder production.

20 The contrasting vegetation layers of wooded grasslands have distinct seasonal dynamics of leaf area and physiological activity. The main woody species is Vachellia erioloba (Camel-thorn tree), which is a deep-rooted semi-deciduous tree with a low leaf turnover rate, resulting in minor leaf area changes. Furthermore, this species has been shown to absorb $37 \%$ of its water below a depth of $1 \mathrm{~m}$, decoupling its physiological activity from recent precipitation and shallow soil water content (Beyer et al., 2018). Perennial $\mathrm{C}_{4}$ grass species at the site have shallower rooting systems and are physiologically responsive to intermittent rainfall events (Sankaran, 2019). Compared to $\mathrm{C}_{3}$ trees, the $\mathrm{C}_{4}$ grass layer has $\mathrm{CO}_{2}$ concentrated in the bundle sheath that enables greater light and water-use efficiencies of $\mathrm{CO}_{2}$ uptake in the warmer intercanopy spaces (Ripley et al., 2010). Due to their ability to regulate intercellular $\mathrm{CO}_{2}$ concentrations, $\mathrm{C}_{4}$ grasses have higher photosynthesis per unit leaf area that can be sustained even in moderate water stress situations (Taylor et al., 2014). However, for the same volume of soil, a $\mathrm{C}_{4}$ grass is an intensive and fast user of soil water when compared to $\mathrm{C}_{3}$ trees. Indeed, due to their shallow rooting depth, severe droughts may alter both their water-use efficiency per unit leaf area and their leaf area dynamics. Thus, our study objective is not only to partition measured ET into $T$ and $E$ but also to quantify the effect of environmental variables on the seasonality of the grass activity. 
Three methods that link $T$ to GPP are used to estimate monthly $T /$ ET. These methods were chosen because previous applications showed some success in partitioning ET into $E$ and $T$ when applied to multi-site data sets. These three methods provide an estimate of ecosystem-scale $T$, albeit with differing assumptions and uncertainty (Stoy et al., 2019). Comparing these methods allows selecting the most suitable partitioning scheme for water-limited ecosystems in general and savannas in particular. Also, an agreement between the methods lends confidence to the estimates of $T / E T$ and the drivers of $T$ (e.g., precipitation). Disagreements between the methods may also identify potential uncertainties for the hydroclimatic or landcover conditions explored here. Hence, a corollary goal is to understand the opportunities and limitations of these methods when combined with eddy covariance-measured ET such as those supplied by FluxNet (Baldocchi et al., 2001).

10 The main question to be addressed here is how $T$ and $T /$ ET vary with $P$ at monthly and annual timescales in a grazed savanna grassland ecosystem. Available MODIS leaf area index (LAI) and enhanced vegetation index (EVI) allow quantifying vegetation dynamics at the site, offering a new perspective on the relation between water fluxes and LAI at seasonal and annual timescales, and ways to examine the role of grass and trees in water budgets. Our study objectives are (i) to quantify the variation in annual $P$, ET, and $T$, (ii) identify the main drivers of the annual and monthly $T$ and $T / \mathrm{ET}$, and (iii) relate the growth

15 dynamics of tree and grass components to the hydrological balance.

\section{Materials and methods}

\subsection{Site description}

The Welgegund measurement site is located in a grazed savanna grassland in South Africa $\left(26^{\circ} 34^{\prime} 10^{\prime \prime} \mathrm{S}, 26^{\circ} 56^{\prime} 2^{\prime \prime} \mathrm{E}, 1480\right.$ m.a.s.1.), shown in Figure 1. The research site is part of a large-scale commercial farm with an annual cattle head count of 1300

$20 \pm 300$. The cattle grazing area is approximately 6000 ha.

The area experiences two seasonal periods: a warm rainy season from October to April and a cool dry season from May to September. The 16-year mean annual rainfall determined at a nearby weather station (town of Potchefstroom) was $540 \mathrm{~mm} \mathrm{yr}^{-}$

${ }^{1} \pm 112 \mathrm{~mm} \mathrm{yr}^{-1}$ (Räsänen et al., 2017). The soil around the site is loamy sand in the top $1 \mathrm{~m}$. Although the water table depth is not known, the farm well has a continuous water supply at $30 \mathrm{~m}$ below the surface (Fig. 1).

The vegetation in the area is an open thornveld. Eragrostis trichophora, Panicum maximum, and Setaria sphacelata are the dominant perennial $\mathrm{C}_{4}$ grass species. The mean maximum grass height across sampling plots was $0.1 \mathrm{~m}$ in 2011 (Räsänen et al., 2017). Tree cover is $15 \%$, and the dominant tree species is Vachellia erioloba, with other less prominent species such as

30 Celtis africana and Searsia pyroides. Dicoma tomentosa, Hermannia depressa, Pentzia globosa, and Selago densiflora are the dominant forb species. Details about the site and vegetation cover may be found elsewhere (Jaars et al., 2016; Räsänen et al., 2017). 

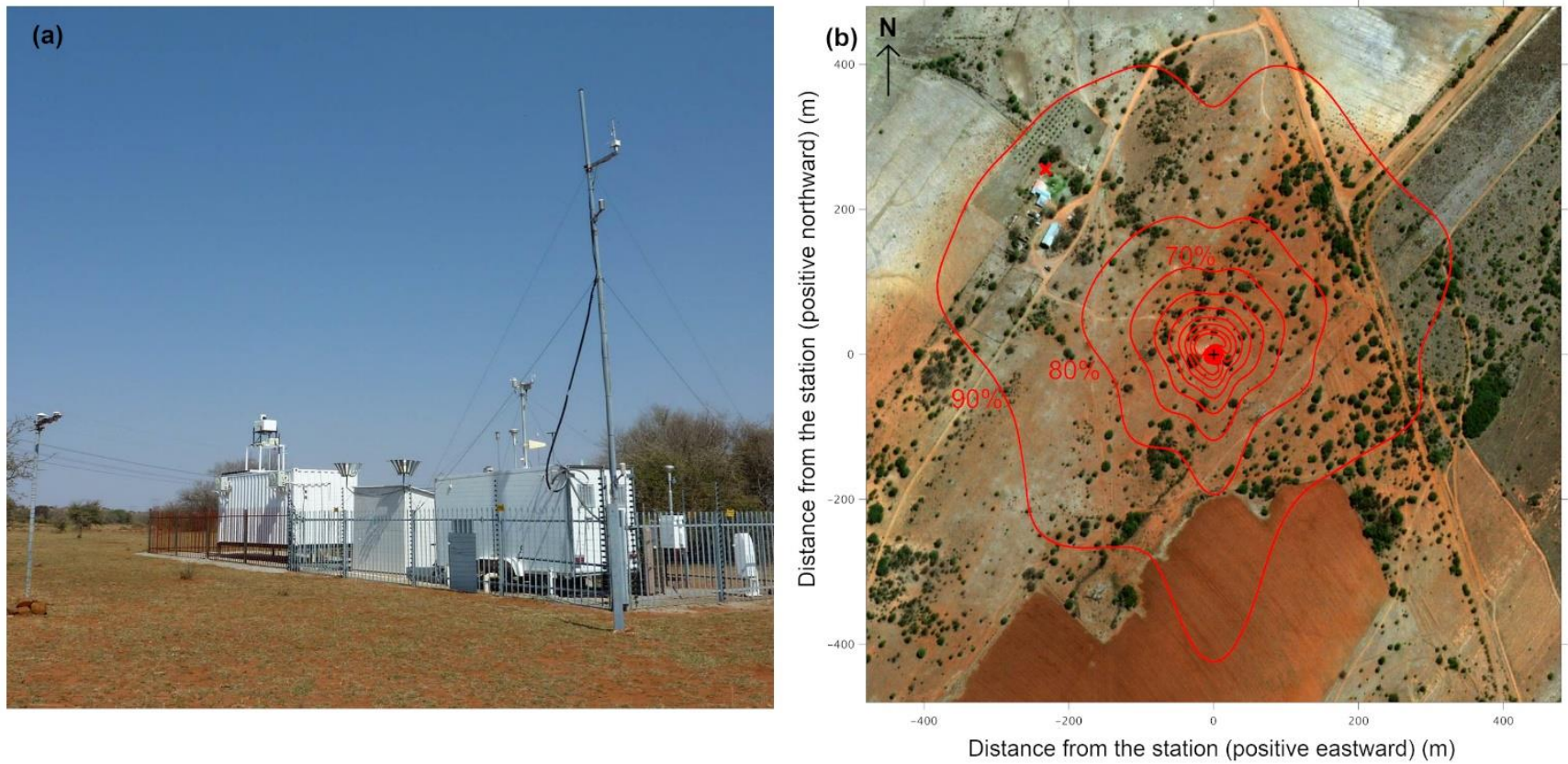

Figure 1 (a) Photograph of the measurement station and surrounding vegetation taken on 22 August 2016. (b) Daytime flux footprint estimated with measured flow statistics and a 2D footprint model (Kljun et al., 2015). Footprint contour lines (red) are shown in $10 \%$ increments from 10 to $90 \%$. The station is located at the center, and the red cross indicates the farm well.

\subsection{Measurements}

Atmospheric aerosols, trace gases, and meteorological variables were measured continuously at the site (Beukes et al., 2015; Petäjä et al., 2013). The measurements directly related to energy fluxes and water balance are briefly described. The eddy covariance (EC) system consisted of a triaxial sonic anemometer (METEK USA-1) and a Li-Cor (LI-7000) closed path infrared

10 gas analyzer, which were positioned $9 \mathrm{~m}$ above the ground surface. The sampling frequency of the EC system was $10 \mathrm{~Hz}$. The gas analyzer was calibrated every month with a high-precision $\mathrm{CO}_{2}$ span gas using synthetic air with $\mathrm{CO}_{2}<0.5$ ppm as a reference gas. The meteorological measurements included atmospheric temperature and pressure, mean wind speed and direction, and mean air relative humidity. The radiation measurements were made using Kipp \& Zonen PAR-lite sensors, CMP-3 pyranometers, and a NR-lite 2 net radiometer positioned $3 \mathrm{~m}$ above the ground with a field of view at the grass level.

15 These sensors measure photosynthetically active radiation (PAR), direct and reflected global radiation, and net radiation. The soil surface heat flux was measured with a Hukseflux HFP01 heat flux plate at $5 \mathrm{~cm}$ below the soil surface. The meteorological variables were sampled every 1 minute (radiation every 10 seconds), and 15 min averages were then recorded.

Precipitation was measured $1.5 \mathrm{~m}$ aboveground with two tipping bucket gauges (Vaisala QMR102 and Casella). Most of the precipitation values reported here are from the Vaisala gauge, with the Casella gauge only used to gap-fill missing values in 
the Vaisala gauge time series. No significant differences were observed between the two sensors. Between December 2011 and February 2012, the measured rainfall was underestimated due to the high intensity of the rainfall, and it was corrected using nearby weather station measurements (Sect. S.1, Fig. S1 and S2). Wind-induced underestimation is a well-known problem with pointwise rainfall measurements. Thus, the measured precipitation was corrected by multiplying the measured precipitation by 1.094 . This corresponds to the $9.4 \%$ bias that was determined for the Casella rain gauge at the height of $0.5 \mathrm{~m}$ at a measurement site with a similar mean wind speed $\left(5 \mathrm{~m} \mathrm{~s}^{-1}\right)$ and annual rainfall $\left(P=700-1000 \mathrm{~mm} \mathrm{yr}^{-1}\right)$ (Pollock et al., 2018).

Stored soil water changes were determined using two separate soil moisture profiles. The measurements of individual soil moisture sensors at depths $0.05,0.2$, and $0.5 \mathrm{~m}$ (Delta-T ML2) were converted to a single average soil moisture value using the weights of 125, 225, and $200 \mathrm{~mm}$. These soil moisture measurements covered the complete experiment period from September 2010 to August 2016. Starting from March 2012 onwards, a Delta-T PR2/6 probe was installed to record soil moisture at $0.1,0.2,0.3,0.4,0.6$, and $1.0 \mathrm{~m}$ depths. This profile measurement was converted to stored soil water using the weights $150,100,100,150,300$, and $200 \mathrm{~mm}$, and it was used to calculate the annual change in soil water storage $\left(\Delta \Theta_{1 \mathrm{~m}}\right)$ over the entire $1 \mathrm{~m}$ soil column.

The site was visited once or twice a week during the six-year period to check the status of the sensors and correct errors if necessary. Measurement records were used to identify anomalies, outliers, or erroneous measurement periods. Further details of the site and EC measurements are presented elsewhere (Aurela et al., 2009; Räsänen et al., 2017). The annual energy balance closure was also verified, which varied from 0.75 to 0.85 . This lack-of-closure is comparable to those reported in FluxNet sites (Stoy et al., 2013; Wilson et al., 2002). Given the heterogeneity in vegetation cover and that EC measurements sense a different footprint from the footprint representing the difference between net radiation and soil heat flux, no Bowen ratio adjustments were performed to force an energy balance closure.

\subsection{Flux calculation and gap-filling}

25 The details of the turbulent flux calculations are presented in Räsänen et al. (2017). Briefly, the turbulent fluxes were calculated as 30 min block averages after double rotation and by applying the Webb-Pearman-Leuning (WPL) density correction (Webb et al., 1980). The low-frequency flux correction was performed according to Moore (1986), and high-frequency losses were corrected using empirical transfer functions determined using sensible heat flux as a reference scalar. The sensible and latent heat flux values were discarded when the measured friction velocity $u_{*}$ was below $0.28 \mathrm{~m} \mathrm{~s}^{-1}$, which was deemed as a state of low turbulence mixing. The steady-state test of Foken and Wichura (1996) was used to screen the latent heat flux data for nonstationary conditions within each 30-min averaging period. The data were discarded if the relative nonstationarity defined by this test exceeded a threshold, which was set to $30 \%$ and $100 \%$ for the data used for gap-filling and final analysis, respectively. Latent heat fluxes were checked for an acceptable $\mathrm{H}_{2} \mathrm{O}$ concentration range and variance to detect anomalous 
spikes due to condensation or rainfall. Heat flux values were filtered for outliers by considering values for each month of all the measurement years and removing outliers using an adjusted boxplot (Hubert and Vandervieren, 2008). The steady-state check resulted in less than $30 \%$ filtered fluxes, which were gap-filled using marginal distribution sampling (MDS) from the REddyProc package (Reichstein et al., 2005). Both daytime and nighttime fluxes were gap-filled using this approach, given

5 the significant role nighttime evaporation and respiration play in the water and carbon balances. Gap-filling of nighttime evaporation is of significance at Welgegund, as most of the rainfall occurs in the late afternoon and early evening. The meteorological parameters were also gap-filled using the MDS approach (Reichstein et al., 2005).

The flux footprint was estimated using the daytime measured flow statistics and a standard 2D footprint model (Kljun et al.,

10 2015), which are presented in Fig. 1. These calculations suggest that $80 \%$ of the ET fluxes originate from the homogeneous thornveld.

The EC-inferred GPP was used to derive the water-use efficiencies to partition measured ET into $T$ and $E$. The measured net ecosystem $\mathrm{CO}_{2}$ exchange (NEE) was partitioned into GPP and ecosystem respiration using nighttime mean respiration values.

15 These values were assumed to be the same for daytime respiration, and GPP was determined as the difference between NEE and daytime ecosystem respiration. Nighttime mean respiration was used instead of the exponential temperature function, as only $2 \%$ of the fitting windows had a linear or exponential relation between EC-based ecosystem respiration and soil temperature. The difference between the mean monthly transpiration from these two methods was small, with transpiration from the exponential temperature function being $4 \%$ higher than transpiration from the nighttime mean method (Fig. S3). The GPP fit parameters and the nighttime mean respiration were calculated in a moving data window that was defined for each day with an initial length of six days. The moving window was expanded by up to 20 days if necessary, to include at least 50 measurement points. The measured NEE had one large 25-day gap in September 2013, and the fit parameters were linearly interpolated for this gap. The preprocessing of NEE was performed with the same filters as the heat fluxes, as discussed in Räsänen et al. (2017).

The potential ET (PET) was calculated using the Priestley-Taylor formulation given by Priestley and Taylor (1972)

$$
P E T=\alpha_{P T} \frac{\Delta}{\Delta+\gamma_{p}}\left(R_{n}-G\right),
$$

where $\alpha_{P T}=1.26$ is the Priestley-Taylor coefficient, $\Delta=\mathrm{d} e^{*} / \mathrm{d} T_{a}\left(\mathrm{~Pa} \mathrm{~K}^{-1}\right), e^{*}(\mathrm{~Pa})$ is the saturation vapor pressure given by the Clausius-Clayperon equation and evaluated at the measured air temperature $T_{a}(\mathrm{~K}), R_{n}\left(\mathrm{~W} \mathrm{~m}^{-2}\right)$ is net radiation, $G\left(\mathrm{~W} \mathrm{~m}^{-}\right.$ $\left.{ }^{2}\right)$ is soil heat flux, and $\gamma_{p}\left(\mathrm{~Pa} \mathrm{~K}^{-1}\right)$ is the psychrometric constant. The energy balance closure (EBC) slope was estimated for

30 each year by regressing all measured half-hourly values of $R_{n}-G$ against the sum of the measured latent and sensible heat fluxes for the same period. 


\subsection{Uncertainty of annual ET estimates}

Friction velocity $\left(u^{*}\right)$ threshold was estimated using a bootstrap technique from 200 artificial replicates of the data set (Wutzler et al., 2018). The mean $u^{*}$ estimate value for the whole data set was $0.28 \mathrm{~m} \mathrm{~s}^{-1}$, with heat flux and NEE values being discarded when $u^{*}$ was lower than this limit. The 5th, 50th, and 95th percentiles of the estimates were $0.27,0.29$, and $0.32 \mathrm{~m} \mathrm{~s}^{-1}$,

5 respectively. The data set was $u^{*}$ filtered and gap-filled with these three $u^{*}$ limits. The annual $u^{*}$ uncertainty range was calculated for each $\mathrm{k}$ year as

$$
E_{u *, k}=\frac{\mathrm{ET}_{\text {max,k }}-\mathrm{ET}_{\text {min,k }}}{\mathrm{ET}_{\text {median }, \mathrm{k}}} \mathrm{ET}_{\mathrm{k}}
$$

where $E_{u * k}$ is the $u^{*}$ uncertainty for year $k$ and $\mathrm{ET}_{\mathrm{k}}$ is the evapotranspiration for year $k$.

The MDS gap-filling algorithm estimates random error for each half-hour value based on the standard deviation of the observed

10 latent heat flux with similar meteorological conditions in a moving window. The annual random error was estimated as rootmean squared error

$$
E_{\text {rand }, k}=\sqrt{\sum_{i=1}^{n_{k}} \sigma_{i}^{2}},
$$

where $n_{k}$ is the number of 30 min periods in year $k$ and $\sigma_{i}$ is the standard deviation of latent heat flux from the MDS gapfilling algorithm. The total uncertainty of the annual ET was calculated by adding the random error and $u^{*}$ uncertainty in

15 quadrature to yield

$$
E_{t o t, k}=\sqrt{E_{u *, k}^{2}+E_{\text {rand }, k}^{2}}
$$

\subsection{Rainfall interception}

The total rainfall interception $\left(I_{t}\right)$ was not measured but estimated by modeling grass, litter, and tree interception. The interception was estimated for each storm using discrete rainfall events separated by at least one hour. The grass interception for one storm event was calculated using an expression derived for crops (Moene and Van Dam, 2014)

$$
I_{\text {grass }}=a \mathrm{LAI}\left(1-\frac{1}{1+\frac{c_{g} P_{g}}{a \mathrm{LAI}}}\right) \text {, }
$$

where $a$ is the scale parameter, $c_{g}$ is the grass cover fraction, LAI is leaf area index estimated here from satellite (Sect. 2.7), ,and $P_{g}$ is the rainfall amount per storm. The scale parameter was set to $0.5 \mathrm{~mm}$ (event) ${ }^{-1}$, which corresponds to a maximal 1 $\mathrm{mm}$ interception loss for $\mathrm{LAI}=2$. The grass cover fraction was estimated using LAI:

$$
c_{g}=1-e^{-k \mathrm{LAI}},
$$

where the extinction coefficient $(k)$ is set to 0.4 . Tree interception was estimated using the revised model for a sparse canopy (Gash et al., 1995). The model assumes that rainfall events consist of wetting, saturation, and drying phases. The interception 
for small events that do not saturate the canopy was estimated separately from large storms that saturate the canopy. The rainfall to fill the canopy storage is

$$
P_{g}^{\prime}=-S_{c}\left(\frac{\bar{R}}{\bar{E}}\right) \ln \left(1-\left(\frac{\bar{E}}{\bar{R}}\right)\right),
$$

where $S_{c}=S / c_{t}$ is the canopy storage capacity per unit cover, $\bar{R}$ is the mean rainfall, and $\bar{E}$ is the mean evaporation rate during

5 a storm. The measured ET was used to calculate the mean evaporation rate for each event. The tree cover fraction $c_{t}$ was set to a constant 0.15 , and storage capacity $S$ was set to $1.07 \mathrm{~mm}$, corresponding to a measured value for $A$. mearnsii (Bulcock and Jewitt, 2012). The total tree interception is then determined as

$$
I_{\text {tree }}=c_{t} \sum_{i=1}^{m} P_{g, i}+\sum_{j=1}^{n}\left[c_{t} P_{g}^{\prime}+c_{t} \frac{\bar{E}}{\bar{R}}\left(P_{g, j}-P_{g}^{\prime}\right)\right] .
$$

The first sum accounts for the $m$ small events that do not saturate the canopy and the second sum accounts for the $n$ large events. The litter interception was assumed to be $1 \mathrm{~mm}$ per rainfall event (Scholes and Walker, 1993) and it was multiplied by $c_{t}$.

\subsection{Partitioning ET}

Prior to presenting the three ET partitioning approaches, the link between GPP and $T$ is reviewed. From definitions, the fluxbased water-use efficiency (WUE) is:

$$
\mathrm{WUE}=\frac{\mathrm{GPP}}{T} \propto \frac{c_{a}}{\mathrm{VPD}}\left(1-c_{i} / c_{a}\right),
$$

where $c_{i}$ and $c_{a}$ are the intercellular and ambient atmospheric $\mathrm{CO}_{2}$ concentrations and VPD is the vapor pressure deficit. Based on stomatal optimization theories that maximize carbon gain for a given amount of water loss in the rooting system per unit leaf area, the ratio of $\mathrm{CO}_{2}$ concentrations $\left(1-c_{i} / c_{a}\right)$ is proportional to $\sqrt{\mathrm{VPD}}$, as demonstrated in several studies reviewed elsewhere (Hari et al., 2000; Katul et al., 2009, 2010). Combining these theories with the definition of WUE (Eq. 5) makes $T$ proportional to GPP $\times \mathrm{VPD}^{0.5}$ provided that $c_{a}$ does not vary appreciably. The proportionality constant in this expression $(T \propto$ $\mathrm{GPP} \times \mathrm{VPD}^{0.5}$ ) is linked to the so-called marginal water-use efficiency (or the Lagrange multiplier in optimal stomatal control theories), which differs from the intrinsic water-use efficiency $i W U E=\left(1-c_{i} / c_{a}\right) c_{a}$. It must be externally supplied or determined from EC measurements during conditions when $T$ approximately equals ET. When this proportionality constant is known, an EC-based GPP estimate (together with VPD) can be used to infer $T$ and, subtracting from ET, produce an estimate of $E$.

Three approaches were used to divide ET into $E$ and $T$ using the above-mentioned link between GPP and $T$ (Table 1). The first method was presented by Berkelhammer et al. (2016), and it is referred to as the Berkelhammer method. Here, it was applied to each year individually to allow for the large inter-annual variation in vegetation phenology. The method assumes that ET is 
linearly related to GPP $\times \mathrm{VPD}^{0.5}$ only when $T$ is the dominant term in ET. Also, the $T / \mathrm{ET}$ ratio is assumed to approach unity intermittently. To estimate the T/ET value for each 30-min period, the product GPP by VPD ${ }^{1 / 2}$ was plotted against ET for each year, and the minimum value of ET was then selected as the fifth percentile for each equal-sized GPP $\times V_{\text {PDD }}^{0.5}$ bin. The bin was defined by discretizing the $30 \mathrm{~min} G \mathrm{GP} \times \mathrm{VPD}^{0.5}$ values into 50 bins, each containing the same number of measurements, but encompassing different value ranges, for reasons provided elsewhere (Berkelhammer et al., 2016). A linear regression line of these bins defines the ET value for which $T$ dominates ET. Any value falling below the line is considered to have $T / E T=1$. For points above the regression line, $T / \mathrm{ET}$ is defined as the ratio between the minimum ET that represents $T$ and the observed ET:

$$
\frac{T}{\mathrm{ET}}=\frac{\min _{\mathrm{GPP}}|| \mathrm{ET}||}{\mathrm{ET}_{\text {flux }}},
$$

10 where $\min _{\mathrm{GPP}} \| \mathrm{ET}||$ is the minimum ET value and $\mathrm{ET}_{\text {flux }}$ is the observed ET value. The calculation of half-hour $T / E T$ values for one year is illustrated in Figure S4. The monthly T/ET values were calculated by taking the mean of these half-hour $T / E T$ values for each month. The regression slope and intercept of the $T=\mathrm{ET}$ line are related to the inverse of water-use efficiency for each year based on the half-hour data. The $30 \mathrm{~min}$ data points used for the T/ET estimation were also filtered with additional quality criteria, i.e. only data points with measured ET, positive GPP, and $R_{n}$ were used (see Zhou et al., 2016). However, rainy

15 days were included in the estimation to capture the rainfall interception events measured by the EC system while maintaining the data-stationarity filter. Shortly after rain, water droplets remaining on the sonic anemometer transducers can block the detection of sound waves emitted and received, leading to anomalous vertical velocity and friction velocity measurements for these 30 min runs. However, as the sonic anemometer transducers are inclined, smooth, and have small surface area, they dry out faster than the leaves, thereby allowing the EC system to operate shortly after each rainfall event. At an annual scale, the estimated $I_{t}$ was used to calculate soil evaporation $\left(E_{s}\right)$ by subtracting $I_{t}$ from $E$.

As previously mentioned, two other methods were also used to estimate $T$ to identify the method most appropriate to waterlimited ecosystems. The second approach, designated the underlying water-use efficiency (uWUE) method, entailed fitting the $T=E T$ line using quantile regression with zero-intercept; the slope of this fitted line is termed uWUEp (Zhou et al., 2016). The 25 slope uWUEp was defined by fitting all six years of 30-min data, resulting in uWUEp $=11.55 \mathrm{gC} h \mathrm{~Pa}^{0.5} / \mathrm{kg} \mathrm{H}_{2} \mathrm{O}$, after which the slopes (uWUEa) were defined for each month separately by fitting the half-hour ET values to GPP $\times \mathrm{VPD}^{0.5}$ values using linear regression with zero intercept. The monthly $T / E T$ value is the ratio of uWUEa slope and uWUEp of each month. The difference between the Berkelhammer method and the uWUE method is primarily in the process of fitting the $T=E T$ line and in the calculation of the monthly $T / \mathrm{ET}$ values.

The third approach is labeled as the transpiration estimation algorithm (TEA) (Nelson et al., 2018), which is a random forest regressor that first isolates the most likely periods when $T$ is equal to ET, after which it trains on GPP and $T$ relations during 
these periods to infer $T$ from measured GPP. A summary of these methods and their requirements is featured in Table 1 for convenience.

An independent check on $E$ was also conducted for certain conditions using analytical solutions to the approximated Richards'

5 equation applied to a uniform soil column. When soil physical properties control evaporation (commonly referred to as stage2 drying), evaporation may be inferred from the desorption properties of the soil. The desorption properties were not measured in this study but were inferred from the soil water retention and soil hydraulic conductivity functions associated with the soil type at the site (sand). This approach is reviewed in the supplementary material (Sect. S.3, Fig. S5) and is only used as an independent plausibility check on $E$.

Table 1. Summary of the ET partitioning methods applied to the 6-year data.

\begin{tabular}{|l|l|l|l|}
\hline Name & Input variables & Method to calculate monthly T/ET & References \\
\hline Berkelhammer & ET, GPP, and VPD & $\begin{array}{l}\text { Monthly T/ET is an average of half-hour T/ET } \\
\text { daytime values that are estimated during the } \\
\text { measured flux periods. }\end{array}$ & Berkelhammer et al. (2016) \\
\hline uWUE & ET, GPP, and VPD & $\begin{array}{l}\text { Monthly T/ET is the ratio of the slope of monthly fit } \\
\text { of GPP } \times \text { VPD }\end{array}$ & $\begin{array}{l}\text { Zhou et al., (2016), Zhou et } \\
\text { slope from the quantile regression of all data } \\
\text { (uWUEp). }\end{array}$ \\
\hline TEA & $\begin{array}{l}\text { ET, } 2018) \\
\text { temperature, and Hu et al., } \\
\text { precipitation, incoming } \\
\text { shortwave radiation, and } \\
\text { wind speed }\end{array}$ & $\begin{array}{l}T \text { and } E \text { are estimated for all half-hour periods, and } \\
\text { monthly T/ET is calculated using the monthly sum } \\
\text { of } T \text { and ET. }\end{array}$ & Nelson et al., (2018) \\
\hline
\end{tabular}

\subsection{Satellite data}

Changes in vegetation cover were quantified using the monthly average of MODIS 16-day EVI with $250 \mathrm{~m}$ spatial resolution

15 (MOD13Q1, collection 6) (Didan, 2015). The monthly average of MODIS 8-day LAI (MOD15A2H, collection 6) with $500 \mathrm{~m}$ spatial resolution was used to relate monthly T/ET to LAI, comparing estimated T/ET to variations in vegetation phenology. The EVI signal is a ratio of spectral bands, whereas the LAI has corrected units of foliage area per ground area. 


\subsection{Rainy season timing and green-up dates}

Rainy season length $\left(T_{w e t}\right)$ was estimated based on a climatological threshold of $5 \%$ of the mean annual rainfall (Guan et al., 2014). The start of the rainy season was defined as the day when cumulative rainfall of the hydrological year (September to

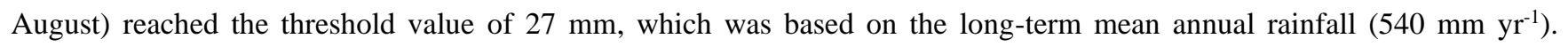

5 Similarly, the end of the rainy season was estimated as the first day when cumulative rainfall, starting backward from the end of the hydrological year (August), reached the same threshold value. Early wet-season (September to November) precipitation was characterized by estimating the mean daily rainfall statistics using the daily mean precipitation amount $(\alpha)$ and daily mean storm frequency $(\lambda)$. The daily mean precipitation amount was calculated as the mean precipitation of rainy days, while the mean storm frequency was calculated as the inverse of the mean time between rainy days.

The tree green-up date, estimated from the raw 16-day EVI time series (Archibald and Scholes, 2007), was defined as the day when the EVI signal was higher than the moving average of the previous four time steps at the beginning of the hydrological year, which is the time when the EVI time series experiences a sudden increase.

\section{Results}

15 Before addressing the study objectives, we first present the variability in precipitation and LAI (or EVI). Next, the outcomes of the three ET partitioning methods summarized in Table 1 are featured. The likely drivers of $\mathrm{E}$ and $\mathrm{T}$ variability at multiple timescales are then outlined, forming the basis for the discussion and the completion of the study objectives. Hereafter, hydrological years are defined as the time period from September to August and are referred to by the year in which they began.

\subsection{Seasonality of precipitation and vegetation}

Rainfall was close to or above the mean annual rainfall of $591 \mathrm{~mm} \mathrm{yr}^{-1}$ (adjusted here for the undercatch) for every year except in 2015, which was an extreme drought year in South Africa (Table 2). This drought year was characterized by annual $P$ that was $83 \mathrm{~mm} \mathrm{yr}^{-1}$ lower than the long-term mean and by rainy season length that was nearly twice as long as in other years (Fig.

25 2a). The early-season rainfall was frequent in all years except 2011 and 2015 (Fig. 2a). However, soil moisture variance during the rainy season was highest in 2011. There was a two-week dry spell at the end of January 2011 and another dry spell at the end of November 2015, which are visible through the low measured ET and soil moisture values (Fig. 2b-c). Grass experienced dieback and regrowth in 2015, leading to the second peak in EVI (Fig. 2e). This period was also characterized by high VPD. The tree green-up days and start of the rainy period were not linearly related (Table $\mathrm{S} 3, R^{2}=0.03, p=0.753$ ): the earliest tree

30 green-up date occurred in 2011, 72 days earlier than the start of the rainy season. The increase of the EVI signal before the start of wet season was likely related to tree leaf green-up and not to grass LAI, which follows the start of the rainy season. 
Table 2. Annual sum of water balance components for each hydrological year (September to August). The total uncertainty (Eq. 4) is indicated for ET after the \pm sign. $E T_{N}$ is the annual nighttime evapotranspiration. The PET determined from Eq. 1 is also shown. Transpiration and evaporation were calculated from monthly T/ET estimates. The EBC slope stands for the slope of the energy balance closure with ordinate, defined by measured $R_{n}-G$ and abscissa defined by the sum of the measured latent and sensible heat

\begin{tabular}{|l|l|l|l|l|l|l|l|l|l|l|l|l|l|}
\hline Year & $P$ & $\mathrm{ET}$ & $\mathrm{ET}_{\mathrm{N}}$ & $P$-ET & $T$ & $E$ & $E_{s}$ & $I_{t}$ & $\Delta \Theta_{1 m}$ & $T / \mathrm{ET}$ & PET & EVI & \\
\hline $\begin{array}{l}(\mathrm{mm} \\
\left.\mathrm{yr}^{-1}\right)\end{array}$ & $\begin{array}{l}(\mathrm{mm} \\
\left.\mathrm{yr}^{-1}\right)\end{array}$ & $\begin{array}{l}(\mathrm{mm} \\
\left.\mathrm{yr}^{-1}\right)\end{array}$ & $\begin{array}{c}(\mathrm{mm} \\
\left.\mathrm{yr}^{-1}\right)\end{array}$ & $\begin{array}{c}(\mathrm{mm} \\
\left.\mathrm{yr}^{-1}\right)\end{array}$ & $\begin{array}{c}(\mathrm{mm} \\
\left.\mathrm{yr}^{-1}\right)\end{array}$ & $\begin{array}{c}(\mathrm{mm} \\
\left.\mathrm{yr}^{-1}\right)\end{array}$ & $\begin{array}{c}(\mathrm{mm} \\
\left.\mathrm{yr}^{-1}\right)\end{array}$ & $\begin{array}{c}(\mathrm{mm} \\
\left.\mathrm{yr}^{-1}\right)\end{array}$ & & $\begin{array}{c}(\mathrm{mm} \\
\left.\mathrm{yr}^{-1}\right)\end{array}$ & & \\
\hline $\begin{array}{l}6010- \\
2011\end{array}$ & 628 & 658 & 68 & -30 & 344 & 313 & 226 & 87 & - & 0.52 & 1133 & 0.32 & 0.75 \\
\hline $\begin{array}{l}2011- \\
2012\end{array}$ & 577 & $\begin{array}{l}608 \\
\pm 10\end{array}$ & 68 & -31 & 268 & 340 & 266 & 74 & - & 0.44 & 1123 & 0.30 & 0.80 \\
\hline $\begin{array}{l}2012- \\
2013\end{array}$ & 672 & $\begin{array}{l}667 \\
\pm 8\end{array}$ & 78 & 5 & 334 & 333 & 251 & 82 & 14 & 0.50 & 1109 & 0.29 & 0.85 \\
\hline $\begin{array}{l}2013- \\
2014\end{array}$ & 580 & $\begin{array}{l}600 \\
\pm 6\end{array}$ & 81 & -20 & 325 & 274 & 184 & 90 & 12 & 0.54 & 1039 & 0.31 & 0.81 \\
\hline $\begin{array}{l}2014- \\
2015\end{array}$ & 636 & $\begin{array}{l}642 \\
\pm 11\end{array}$ & 85 & -6 & 320 & 322 & 225 & 97 & 3 & 0.50 & 1057 & 0.27 & 0.83 \\
\hline $\begin{array}{l}2015- \\
2016\end{array}$ & 508 & $\begin{array}{l}463 \\
\pm 6\end{array}$ & 58 & 45 & 175 & 288 & 219 & 69 & -1 & 0.38 & 1038 & 0.22 & 0.84 \\
\hline Mean & 600 & 606 & 73 & -6 & 294 & 312 & 228 & 83 & 7 & 0.48 & 1083 & 0.28 & 0.81 \\
\hline SD & 53 & 69 & 10 & 26 & 59 & 24 & 26 & 9 & 6 & 0.05 & 40 & 0.03 & 0.03 \\
\hline
\end{tabular}




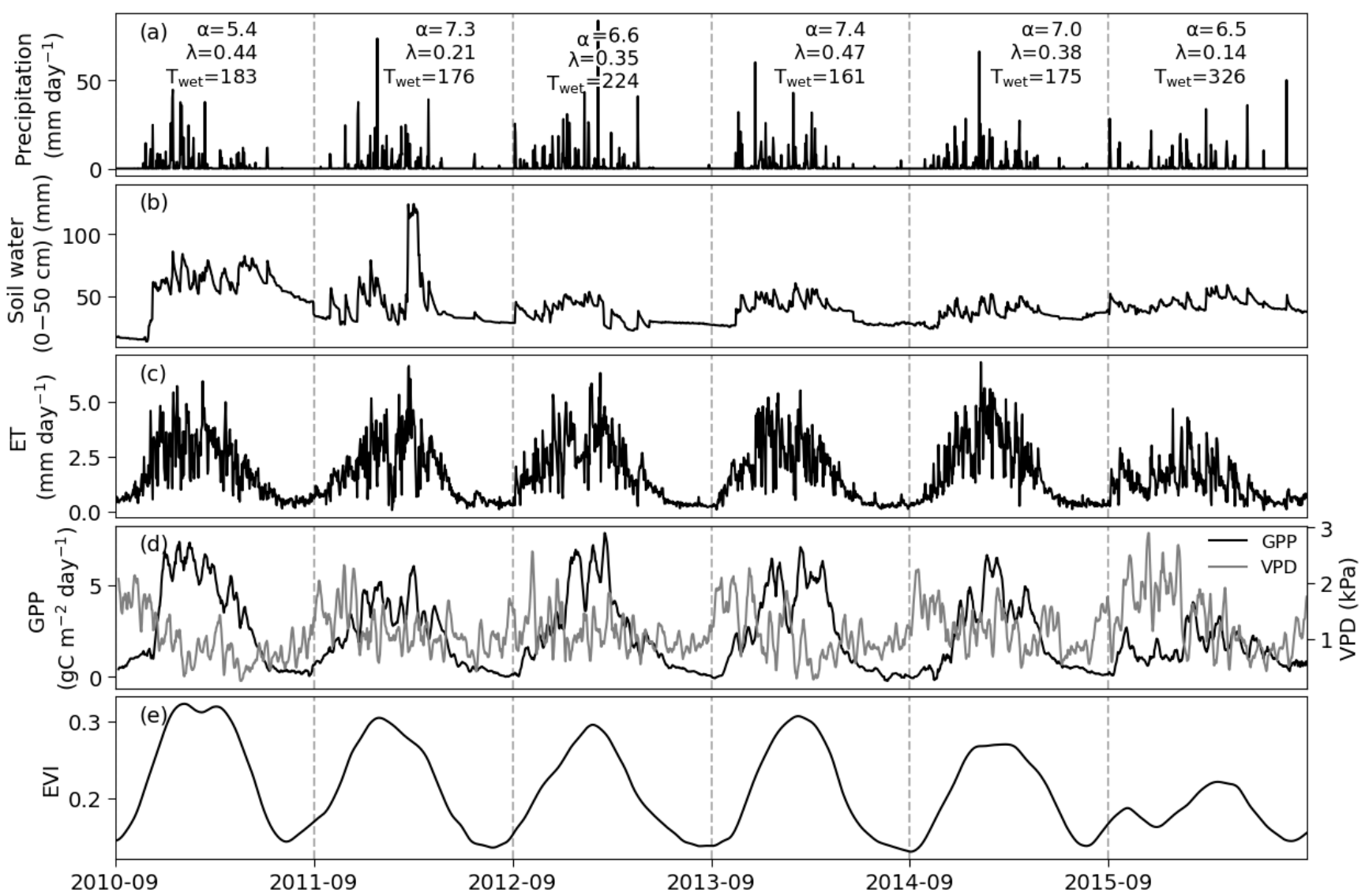

Figure 2. Time series of daily precipitation, soil water (0-50 cm depth), EC-based evapotranspiration, GPP, VPD, and EVI. The GPP and VPD lines show the 7-day running mean. Rainy season length $T_{\text {wet }}$ (days), daily mean precipitation amount $(\lambda)$, and storm frequency $(\alpha)$ for the early wet season (September to November) are indicated for each year in the top panel.

\section{$5 \quad 3.2 \quad$ ET partitioning and monthly transpiration}

In the Berkelhammer method, the annually fitted line between the variable GPP $\times \mathrm{VPD}^{0.5}$ and ET established the empirical link between GPP and $T$. The bin values of the variable GPP $\times \mathrm{VPD}^{0.5}$ were linearly related to the fifth percentile of measured ET (Fig. 3), with the largest scatter occurring during the drought year $\left(R^{2}=0.85\right.$, in 2015). The GPP $\times \operatorname{VPD}^{0.5}$ values versus ET points were not similarly distributed every year. Years 2011 and 2013 had the same annual ET (Table 2), although more variation in ET values occurred in 2011 for each $\mathrm{GPP} \times \mathrm{VPD}^{0.5}$ bin. For all years, the mean surface soil moisture during $T=\mathrm{ET}$ instances was $0.1 \mathrm{~m}^{3} \mathrm{~m}^{-3}$ or less (Table S3). The annual slope of the $T=E T$ was related to the rainy season length, with year 2011 falling below the $95 \%$ confidence interval of the mean (Fig. 4a). The slope represents the $T=$ ET values, and only $67 \%$ of those values were from the rainy season in 2011 , as opposed to $75-84 \%$ in the other years (Table S3). The greater slope value in 2011 means lower water-use efficiency. The slope and intercept of the $T=E T$ line were also linearly related (Fig. 4b). Thus, 
https://doi.org/10.5194/hess-2021-292

Preprint. Discussion started: 9 August 2021

(c) Author(s) 2021. CC BY 4.0 License.

when most $T=\mathrm{ET}$ values are observed during the rainy season, it is possible to estimate the annual $T=\mathrm{ET}$ line based only on the rainy season length.

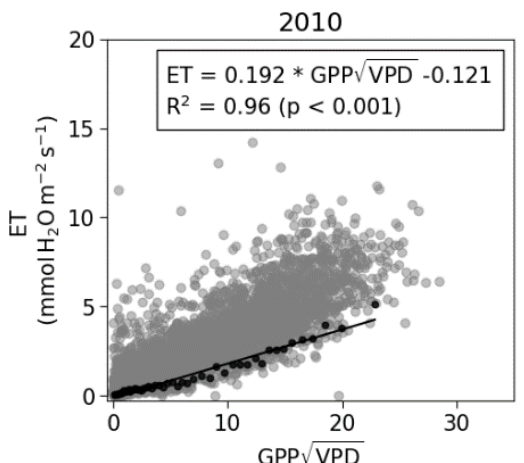

(umolC $\mathrm{m}^{-2} \mathrm{~s}^{-1} \sqrt{\mathrm{hPa}}$ )

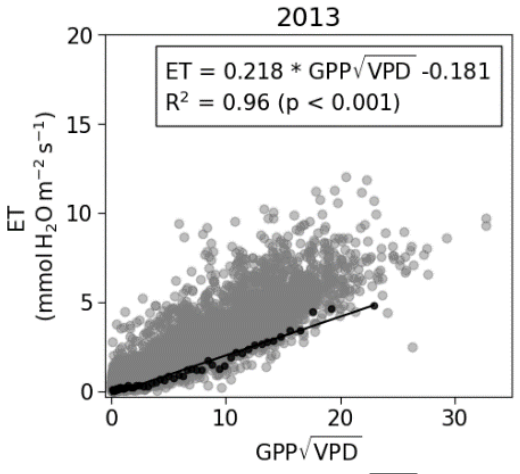

(umolC $\mathrm{m}^{-2} \mathrm{~s}^{-1} \sqrt{\mathrm{hPa}}$ )

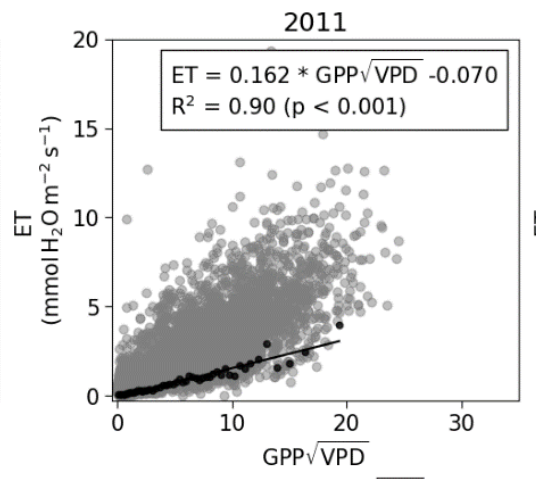

(umolC m $\mathrm{m}^{-2} \mathrm{~s}^{-1} \sqrt{\mathrm{hPa}}$ )

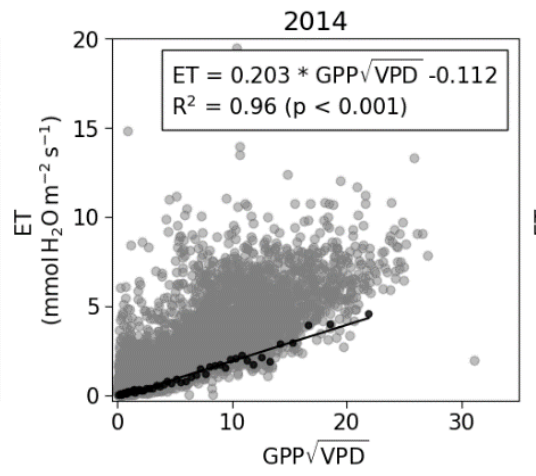

(umolC m $\mathrm{m}^{-2} \mathrm{~s}^{-1} \sqrt{\mathrm{hPa}}$ )

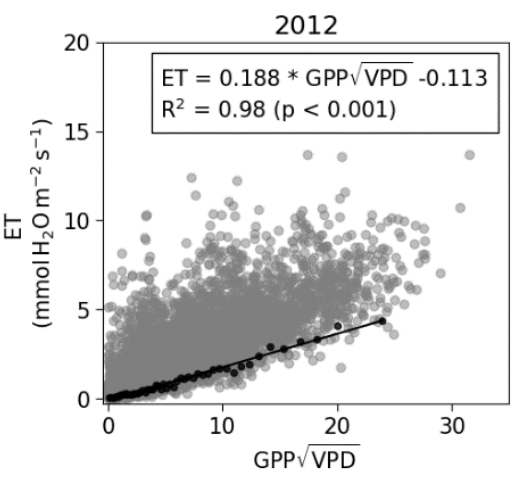

(umolC $\mathrm{m}^{-2} \mathrm{~s}^{-1} \sqrt{\mathrm{hPa}}$ )

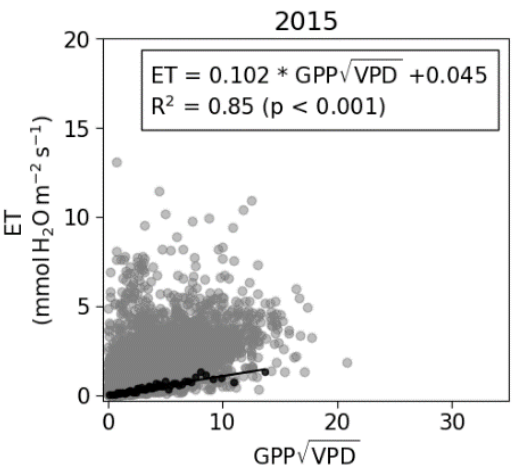

(umolC $\mathrm{m}^{-2} \mathrm{~s}^{-1} \sqrt{\mathrm{hPa} \text { ) }}$

Figure 3. The determination of the $T=E T$ line for each year (Berkelhammer method). The $x$-axis is discretized into 50 equal-sized 5 bins, and one black dot is the minimum (fifth percentile) of the bin. Linear regression is fitted to these minimum values. The gray dots indicate the half-hour data points for which the T/ET ratio is determined. 

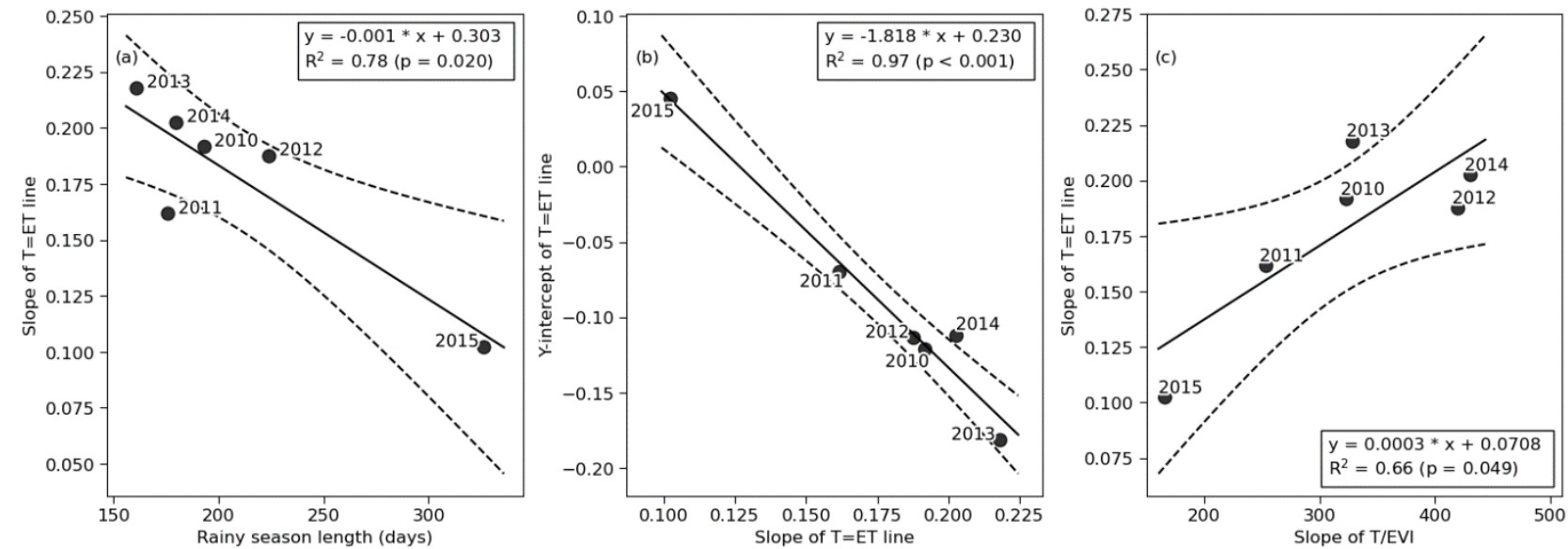

Figure 4. (a) Relationship between the slope of $T=E T$ line and rainy season length. (b) Relationship between the y-intercept and the slope of the $T=E T$ line. (c) Relationship between the slope of $T=E T$ line and annual slope of $T / E V I$ (Fig. S6). Dashed lines demarcate the $95 \%$ confidence interval.
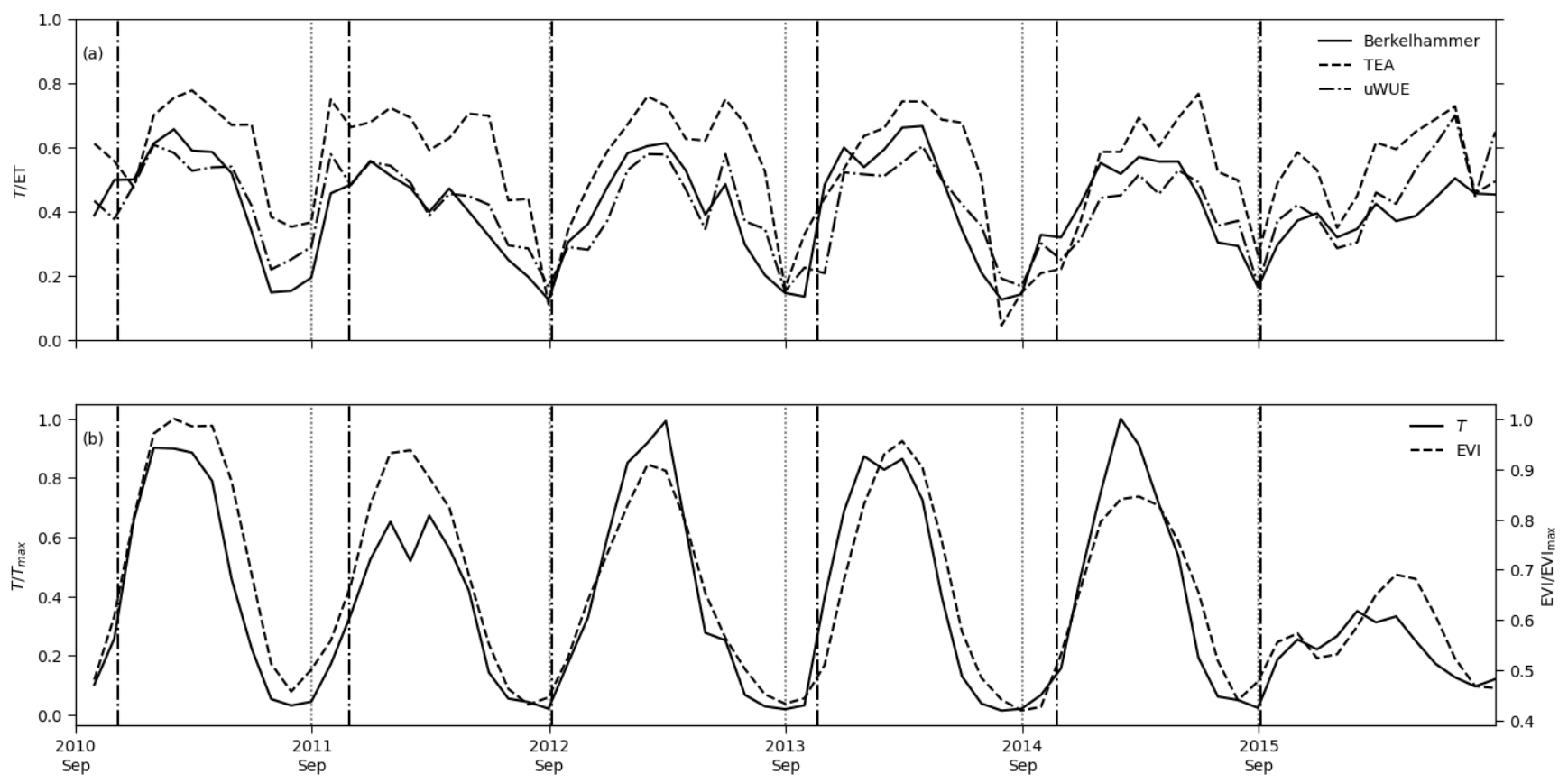

Figure 5. (a) Time series of monthly T/ET estimated with the Berkelhammer, uWUE, and TEA methods. (b) Time series of monthly $T$ and EVI. The dotted vertical line indicates the start of the hydrological year (September 1st), and the dash-dotted line indicates the start of the rainy season. 
A comparison of the three different monthly T/ET estimates shows that $T / E T$ according to the TEA method is consistently higher than with the other two methods during the wet season (Fig. 5a). The annual maximum T/ET determined with the TEA method has a small variance compared to the maximums obtained by the other two methods. The largest difference between T/ET estimated with the uWUE and Berkelhammer methods occurred from March to June 2015 (Fig. 5a). During that period, the monthly GPP decreased, while T/ET increased according to all methods. However, the increase based on the Berkelhammer method is small relative to the other two methods. In June 2016, Berkelhammer-based T/ET was 28\% lower than the uWUEbased T/ET for an EVI value that is half of the typical wet season maximum value. The T/ET values in the late wet season of 2015 based on the TEA and uWUE methods are likely overestimates, given the decrease in GPP and low EVI values during this drought year.

The seasonal trend of monthly T/ET varied between the years (Fig. 5a) and led to a monthly LAI to T/ET relation that was scattered (Fig. 6a). For the whole six-year period, the root-mean-squared error of the LAI to T/ET relation was lower for the Berkelhammer method than for the uWUE method, and the VPD response of monthly GPP/T was more non-linear than the uWUE estimate (Fig. 6a-b). Years with infrequent early-season rainfall were characterized by decreasing LAI to T/ET relations and an LAI range that averaged $37 \%$ less than during the frequent-rain years (Fig. 6c-d). The monthly T/ET was consistently higher in 2013 than in 2012 for the same LAI range due to a higher early-season precipitation frequency (Fig. 6c).

The largest changes in the seasonal cycle of monthly $\mathrm{T}$ were observed during the early and mid-wet seasons (Fig. 5b). Years 2012 and 2014 had similar annual ETs (Table 2), but the rainy season began 48 days later in 2014. This delay is consequently reflected in the monthly course of $T$ in 2014, which lagged behind that of 2012 until January (Fig. 5b). The monthly EVI lagged behind the monthly $T$ in 2013, a year characterized by frequent early-season rainfall. The dry spell in 2011 is clearly shown by reduced $T$ and ET during this period. The monthly EVI and $T$ were linearly correlated each year (Fig. S6), and the slope of $T / E V I$ was linearly related to the slope of the $T=$ ET line (Fig. 4c). This implies that the $T$ for a dry year is smaller per unit of EVI than for a wet year. Years 2012 and 2014 had similar T/EVI slopes, but the T=ET slope was higher in 2014, which means that the shorter rainy season in 2014 resulted in lower water-use efficiency compared to 2012.

The monthly $T$ and GPP were linearly related (Fig. S7 $R^{2}=0.93, p<0.001$ ), allowing for an estimate of an effective (constant) ecosystem water-use efficiency using a zero-intercept regression. The inverse of the constant water-use efficiency was $95 \mathrm{~g}$ $\mathrm{H}_{2} \mathrm{O} / \mathrm{g} \mathrm{CO}_{2}$ (Fig. S7), while the mean annual fitted inverse of the water-use efficiency was $95 \pm 11 \mathrm{~g} \mathrm{H}_{2} \mathrm{O} / \mathrm{g} \mathrm{CO}_{2}$. 

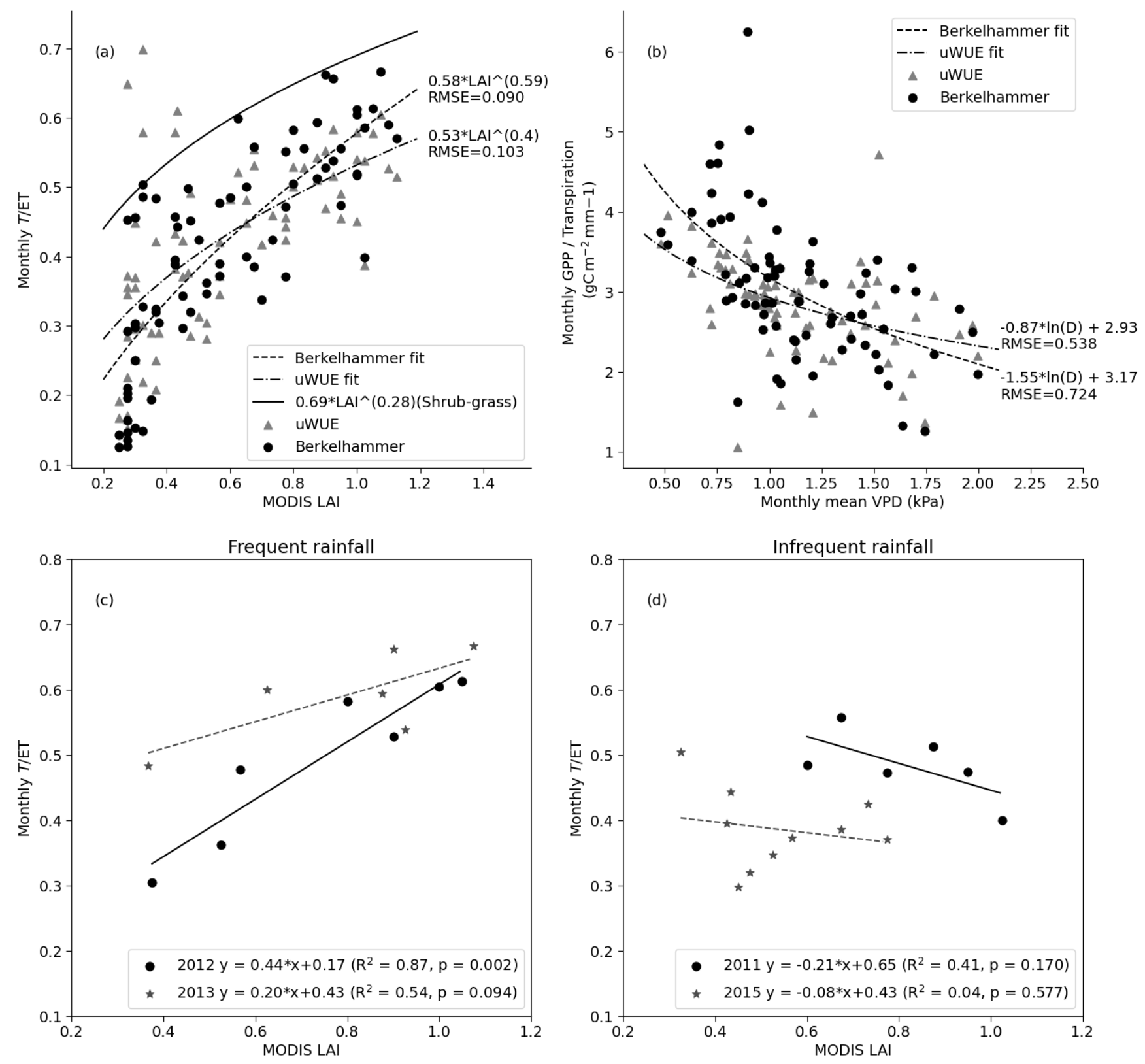

Figure 6. (a) Relationship between monthly T/ET and MODIS LAI. The black line is the relationship for shrub and grass ecosystems (Wei et al., 2017). (b) The relationship between monthly GPP/Transpiration and monthly mean VPD. Rainy season relationship between monthly T/ET (Berkelhammer method) and MODIS LAI for years with (c) frequent early wet-season rainfall (2012 and 2013) and (d) infrequent early wet-season rainfall (2011 and 2015). 


\subsection{Interannual variation}

Annual $P$ was close to the EC-measured annual ET for all years (Table 2). The annual $P$-ET ranged from -31 to $45 \mathrm{~mm} \mathrm{yr}^{-1}$, and it was inversely related to the annual maximum EVI (Fig. $7 \mathrm{a}, R^{2}=0.87, p=0.007$ ). The annual change in soil water storage was small ( 1 to $\left.14 \mathrm{~mm} \mathrm{yr}^{-1}\right)$ compared to the variation in other water balance components and unrelated to the annual

$5 P$-ET $\left(R^{2}=0.45, p=0.332\right)$. The frequent evening and nighttime precipitation resulted in nighttime evapotranspiration $\left(\mathrm{ET}_{\mathrm{N}}\right)$, which varied from 58 to $85 \mathrm{~mm} \mathrm{yr}^{-1}$ (12\% of annual ET). The annual $P$-ET would be positive for all years if $\mathrm{ET}_{\mathrm{N}}$ were assumed to be zero. The annual estimated rainfall interception ranged from 69 to $97 \mathrm{~mm} \mathrm{yr}^{-1}$, linearly related to $\mathrm{ET}_{\mathrm{N}}\left(R^{2}=0.75, p=\right.$ $0.025)$.

10 The estimated annual T/ET ratio varied from 0.38 to 0.54 (Table 2), linearly related to early wet-season storm frequency (Fig. $\left.7 \mathrm{~b}, R^{2}=0.96, p<0.001\right)$. Therefore, the annual $T / \mathrm{ET}$ is determined by rainfall timing and not by rainfall amount, as highlighted by year 2013 when annual T/ET was highest and annual $P$ was close to the long-term mean. The annual $T / E T$ was the same for the wet years 2012 and 2014, despite the late start of the rainy season in 2014. Years 2011 and 2015, with infrequent earlyseason rainfall, had lower annual $T /$ ET ratios and $T \mathrm{~s}$, partly explained by the dry spells during the rainy season that led to a decline in $T$. However, the annual ET was still equal to $P$ during the drought year 2015. Annual transpiration was nearly constant at $331 \pm 11 \mathrm{~mm} \mathrm{yr}^{-1}$ for the four years with frequent early-season rainfall. The average dry-season transpiration was $9 \mathrm{~mm}$ (over three months) ${ }^{-1}$ (Table S2), which suggests a minimum tree transpiration of $36 \mathrm{~mm} \mathrm{yr}^{-1}$.
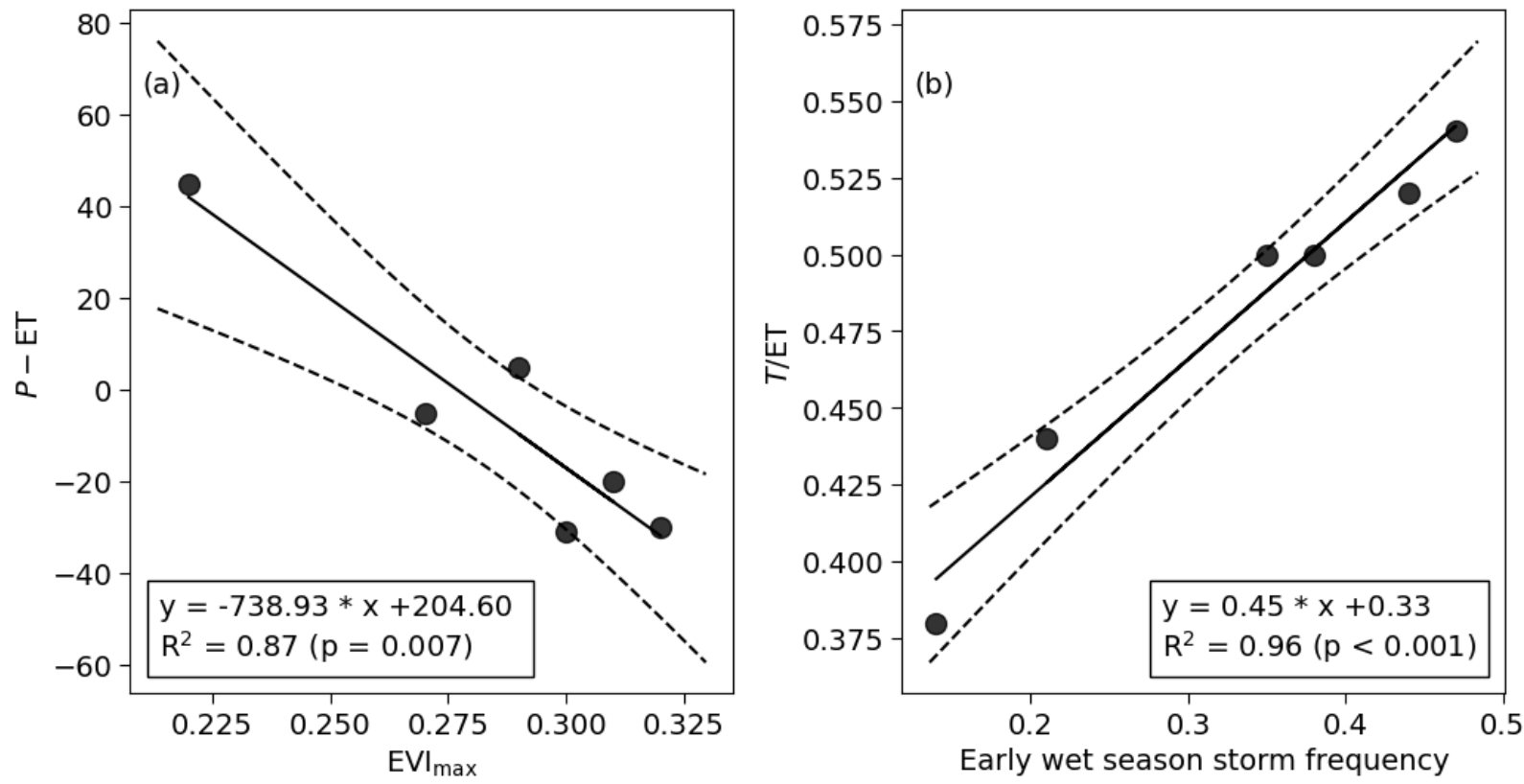

Figure 7. (a) Relationship between annual $P$-ET and maximum EVI. (b) Relationship between annual T/ET and early wet-season 


\section{Discussion}

At annual timescales, $P$ was approximately equal to annual ET, consistent with other studies from sites with similar annual rainfall (Gwate et al., 2018; Scholes and Walker, 1993). Annual $T$ was nearly constant (331 $\pm 11 \mathrm{~mm} \mathrm{yr}^{-1}$ ) during the four years with frequent early wet-season precipitation (Table 2), as has been found in different types of forest ecosystems (Oishi et al.,

5 2010; Tor-ngern et al., 2017; Ward et al., 2018). However, it was lower in years with infrequent early wet-season rainfall producing intermittent dry spells. The variation in annual T/ET was explained by the variation in early wet-season storm frequency (Fig. 7b). While monthly transpiration was linearly related to monthly EVI each year (Fig. S7), transpiration was lower per unit EVI during the dry years (Fig. 4c). Similarly, the monthly T/ET had an expected non-linear relation to LAI, with appreciable difference in the relation between wet and dry years (Fig. 6). Annual $T$ varied little between years with

10 frequent precipitation, reflecting moderate water stress of $\mathrm{C}_{4}$ grasses, which was potentially exacerbated by grazing pressure that limits the grass leaf area. However, the $\mathrm{C}_{4}$ grasses reacted to dry spells by limiting transpiration and to extreme drought followed by drought-breaking rains via a dieback-regrowth cycle that alters the grass leaf area dynamics. The rainfall timing control on annual T/ET and the EVI control of annual P-ET (Fig. 7a) suggest that the growth of the grass layer and especially its early development foreshadow the interannual variation in $T / \mathrm{ET}$ and ET.

\section{$15 \quad 4.1 \quad$ Transpiration}

The small interannual variation in transpiration during the frequent early rainfall years is likely due to the $\mathrm{C}_{4}$ grass layer that experienced only moderate water stress. The photosynthesis reduction in $\mathrm{C}_{4}$ grass is more related to non-stomatal limitations compared to $\mathrm{C}_{3}$ grass, which is predominantly limited by stomatal control (Ripley et al., 2010). In South African field conditions over one growing season, the $\mathrm{C}_{4}$ grass layer tended to maintain a constant difference between predawn and midday

20 leaf water potential, with transpiration being similar at rain-fed and irrigated pot trials (Taylor et al., 2014). The seasonal course of transpiration at Welgegund was similar in wet years and only shifted in time due to different start dates of the rainy season (Fig. 5b). A rainfall timing experiment with $\mathrm{C} 4$ grass in growth chambers showed no difference in the grass biomass between grass grown under frequent light showers and under infrequent rainfall (occurring every 12 days) (Williams et al., 1998). However, the significant reduction in $T$ in 2011 compared to wet years with similar LAIs and ETs suggests that the $\mathrm{C}_{4}$ grasses may quickly reduce $T$ during dry spells (Fig. 5b). During the 2015 drought year, the grass cover underwent a dieback-regrowth cycle in concert with precipitation and the annual $T$ was reduced by $47 \%$ from the mean of wet years. Bare soil cover, soil surface properties, and an increased proportion of the total transpiration from tree transpiration affected the monthly transpiration during that period. This grass growth pattern was also observed in Kruger National Park, where the grass biomass decreased and vast areas were barren during the drought, but the grasses quickly recovered once the rains returned (Wigley-

Coetsee and Staver, 2020). 
The trees at Welgegund are likely decoupled from recent precipitation and shallow soil moisture. Welgegund is located at the wet end of the distribution range of the dominant tree species Vachellia erioloba. The estimated radiocarbon age of these trees is approximately 20 years (Steenkamp et al., 2008). The roots of $V$. erioloba are deep and reportedly extend to a depth of up to $60 \mathrm{~m}$ (Jennings, 1974); in one study, the roots absorbed 37\% of the transpired water below a depth of $1 \mathrm{~m}$ (Beyer et al.,

5 2018). In addition, the horizontal extent of the roots of this species can exceed $20 \mathrm{~m}$ (Wang et al., 2007). The first tree roots were observed at a $0.4 \mathrm{~m}$ depth and $15 \mathrm{~m}$ away from the nearest tree when soil moisture profile measurements at the site were installed. As context for the tree transpiration found here (minimum $\left.36 \mathrm{~mm} \mathrm{yr}^{-1}\right)$, at a savanna site in this region $(\mathrm{P}=241 \mathrm{~mm}$ $\mathrm{yr}^{-1}$ ), V. erioloba (5 $\mathrm{m}$ tall) had an annual/dry-season transpiration ratio of 3.9/0.6 $\mathrm{mm} \mathrm{d}^{-1}$ (Tfwala et al., 2019). Multiplying this ratio with the $9 \mathrm{~mm}$ dry-season tree transpiration in our study results in $59 \mathrm{~mm} \mathrm{yr}^{-1}$ annual tree transpiration. This is comparable to $87 \mathrm{~mm} \mathrm{yr}^{-1}$ annual transpiration at a site $\left(\mathrm{P}=280 \mathrm{~mm} \mathrm{yr}^{-1}\right)$ with deep-rooted $V$. tortillis trees in Senegal, comprising $11 \%$ of the ground cover (scaled sap flow measurements; Do et al., 2008). Finally, at a site in South Africa (Nylsvley) $\left(\mathrm{P}=586 \mathrm{~mm} \mathrm{yr}^{-1}\right)$ with shallower tree roots and a higher ET/P ratio, trees comprising 30\% cover transpired 126 $\mathrm{mm} \mathrm{yr}^{-1}$ (measurements and modeling; Scholes and Walker, 1993). Adjusting this estimate by the $15 \%$ fractional tree cover at Welgegund yields a $T$ estimate of $63 \mathrm{~mm} \mathrm{yr}^{-1}$ for the Welgegund site. According to these estimates, the annual tree transpiration

15 at the site here may range from 59 to $87 \mathrm{~mm} \mathrm{yr}^{-1}$, which is less than $30 \%$ of yearly transpiration. Furthermore, the dominance of grass transpiration is supported by the estimated long-term inverse of water-use efficiency that was $95 \pm 11 \mathrm{~g} \mathrm{H}_{2} \mathrm{O} / \mathrm{g} \mathrm{CO}_{2}$. This is relatively close to the field-scale long-term grass community value of $127 \mathrm{~g} \mathrm{H}_{2} \mathrm{O} / \mathrm{g} \mathrm{CO}_{2}$ but much lower than the combined tree and grass value of $420 \mathrm{~g} \mathrm{H}_{2} \mathrm{O} / \mathrm{g} \mathrm{CO}_{2}$ for the aforementioned shallower rooted trees and $30 \%$ tree cover savanna at Nylsvley (Scholes and Walker, 1993).

During water-stressed years, the partitioning of tree and grass contribution to LAI and T/ET may be needed to derive meaningful relations at the monthly scale (Fig. 6d). Our analysis does not allow for disentangling whether the monthly $T /$ ET to LAI relationships are due to grass or bare soil evaporation, i.e. surface heterogeneity. New remote sensing products may be able to separate these contributions, as shown by a recent study that successfully separated tree and grass leaf area using a canopy height model, Sentinel vegetation indexes (10 m spatial resolution), and a Sentinel radar band during the 2015 drought in Kruger National Park (Urban et al., 2018). The effect of dieback-regrowth on annual transpiration is also interesting, as a stochastic model based on measured precipitation statistics with explicit bare soil, grass, and tree cover showed that vegetation dynamics had little effect on annual transpiration (Williams and Albertson, 2005).

30 Water availability for grass is the determining factor in transpiration at Welgegund. This agrees with a long-term observation from a $\mathrm{C}_{4}$ grassland site in southeastern Arizona, USA $\left(\mathrm{P}=317 \mathrm{~mm} \mathrm{yr}^{-1}\right)$ that estimated the mean annual $T / \mathrm{ET}$ to range from 0.35 to 0.46 using four methods and finding the annual T/ET to correlate with annual $P$ and mean LAI (Scott et al., 2021). The analysis of the different $\mathrm{C}_{4}$ grass species during the 2014-2016 South African drought suggests that their bundle sheath morphology explains the differences in drought tolerance (Wigley-Coetsee and Staver, 2020). Therefore, it is difficult to 
generalize whether the invariance of annual transpiration during the wet years would hold for sites with higher grass LAI or different grass species composition.

\subsection{Uncertainty}

The six-year mean annual ET was $606 \mathrm{~mm} \mathrm{yr}^{-1}$, which is lower than the mean annual ET of $696 \mathrm{~mm} \mathrm{yr}^{-1}$ estimated based on

5 the Bowen ratio over four years in a similar high-altitude grassland but with much higher annual rainfall $(P=1092-1469 \mathrm{~mm}$ $\mathrm{yr}^{-1}$ ) (Everson, 2001). The lowest annual $P$-ET was $-31 \mathrm{~mm} \mathrm{yr}^{-1}$, which is more negative than the estimated annual ET uncertainty but less than the uncertainty related to $\mathrm{ET}_{\mathrm{N}}$ gap-filling (Table 2). Due to frequent afternoon and nighttime precipitation, the $\mathrm{ET}_{\mathrm{N}}$ was $12 \%$ of the annual $\mathrm{ET}$. The $\mathrm{ET}_{\mathrm{N}}$ values here may appear high but are commensurate with reported

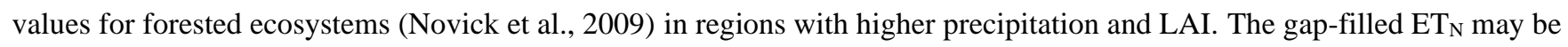

10 an overestimate because only $30 \%$ of the values were measured and these values were determined during high wind speeds $\left(u_{*}>0.28 \mathrm{~m} \mathrm{~s}^{-1}\right)$.

The ratio of annual ET uncertainty to annual ET was $1.3 \%$, which is lower than the 5 to $9 \%$ range reported from eddy covariance ET measurements from a cultivated area in Benin (Mamadou et al., 2016). The difference can be ascribed to

15 different error terms used in the uncertainty estimation. The mid-dry season ET ranged from 45 to $68 \mathrm{~mm}(3 \mathrm{months})^{-1}$ (middry monthly value multiplied by three) at this cultivated site in Benin that has isolated trees (height $<10 \mathrm{~m}$ ) and bare soil during the dry season (Mamadou et al., 2014, 2016). This is higher than the 29 to $52 \mathrm{~mm}$ (three month) $)^{-1}$ range measured in our study. These differences may be attributed to the relatively shallow water table (a depth of $3 \mathrm{~m}$ during the dry season) and the higher annual precipitation $\left(P=1200 \mathrm{~mm} \mathrm{yr}^{-1}\right)$ at the Beninese site.

\section{$20 \quad 4.3 \quad$ ET partitioning methods}

The Berkelhammer and uWUE transpiration estimates were more similar and closer to reported grassland T/ET values than the TEA estimate (Fig. 5a). The TEA estimate was also higher than the uWUE estimate at the $\mathrm{C}_{4}$ grassland site in southeastern Arizona, USA (Scott et al., 2021). The largest difference between the Berkelhammer and uWUE methods was observed during the late wet season and the dry season of the 2015 drought year (Fig. 5a). During these periods, the uWUE and TEA estimated

25 that T/ET values were high (up to 0.7), while GPP and EVI were low. The uWUE method produced high T/ET values at low LAI, which exceeded the published values of a shrub-grass T/ET vs. LAI relationship derived from multiple sites (Fig. 6a, Wei et al., 2017). For the uWUE method, a one-to-one $T=E T$ line is fitted using quantile regression for all six years combined with the intercept forced through zero. This constant $T=$ ET line for the whole data set rather than the separate annual lines, and the quantile regression are likely reasons for the difference between the uWUE and Berkelhammer methods. The TEA algorithm

30 does not use measured soil moisture in the training period, but instead uses $P$ and ET water balance, which may explain the small interannual variance of the maximum T/ET values (Nelson et al., 2018). 
The low surface soil moisture values during $T=E T$ periods and their concentration during the rainy season give assurance that the annual fitted $T=E T$ lines correspond to periods when $T$ equals ET (Table S3). The annual T=ET line could be predicted using the rainy season length, except in 2011, which experienced the earliest green-up of trees and highest number of T=ET moments outside the rainy season (Fig. 4a, Table S3). The water balance analysis, focused on monthly and annual timescales using the ET partition methods, has shown good agreement with independent estimates (Berkelhammer et al., 2016; Zhou et al., 2018). Berkelhammer showed that a 3-day running mean of the half-hour T/ET estimates reduced the root-mean-square difference between the Berkelhammer method and the isotopic estimate of T/ET to $\leq 0.2$ (Berkelhammer et al., 2016). Therefore, the random error of the monthly means of the half-hour T/ET estimates in this study can be assumed to be small. For a Mediterranean tree-grass savanna, T/ET was shown to rarely exceeded 0.8 (Perez-Priego et al., 2018). In contrast to the

10 Mediterranean site, the Welgegund site has sandy soil, deep-rooted trees, and no clay horizon close to the soil surface. More importantly, the mean surface soil moisture was $0.1 \mathrm{~m}^{3} \mathrm{~m}^{-3}$ or below for the half-hour runs when $T=\mathrm{ET}$ at Welgegund. This low soil moisture resulted in small diffusion-limited soil evaporation and thus periods when $T$ equals ET. This is another independent confirmation of the partitioning of ET into $E$ and $T$ (even at such short timescales). A separate analysis (Supplement S.3) confirms that inferred $E$ from the Berkelhammer method is similar to desorption-based estimates during

15 periods when trees and bare soil dominate the land cover. This agreement lends confidence to this method's application for dry conditions (absence of grass).

\section{Conclusion}

The reported measurements here show that the annual transpiration is nearly constant during years with frequent early-season rainfall but can be lower because the $\mathrm{C}_{4}$ grass cover reacts to dry spells and extreme drought. Deep-rooted trees appear to have

20 limited effects on the interannual variance of $T$ and ET, as shown in a patchy tree-grass Mediterranean ecosystem (Montaldo et al., 2020). Our work highlights precipitation control over $T$ and the annual variation in the $T$ to LAI relationship. These results can be used to assess the water resources and fodder production of grassland grazing systems. Although further work is required to determine the generality of these conclusions to other savanna systems, the methodologies developed and tested here can be employed when investigating a wide range of arid and semi-arid ecosystems experiencing water shortages in times of drought.

\section{Data availability}

The data used in this study are available online https://doi.org/10.6084/m9.figshare.11322464 (Räsänen et al., 2019). 
https://doi.org/10.5194/hess-2021-292

Preprint. Discussion started: 9 August 2021

(c) Author(s) 2021. CC BY 4.0 License.

\section{Author contributions}

MR, RO, and GK designed the analysis; VV, MA, and JT performed the EC data processing. MA, VV, PB, JT, PVZ, MJ, SS,

TL, LL, MK, JR conducted the measurements. All authors contributed to the final version of the manuscript.

\section{Competing interests}

5 The authors declare that they have no conflict of interest.

\section{Acknowledgments}

This work was supported by the Finnish Meteorological Institute, North-West University, the University of Helsinki, the Finnish Academy project Developing the atmospheric measurement capacity in Southern Africa, and the Finnish Centre of Excellence, grant no. 272041. This publication forms part of the output of the Biogeochemistry Research Infrastructure

10 Platform (BIOGRIP) of the Department of Science and Innovation of South Africa. This work was partially funded by the European Commission through the project "Supporting EU-African Cooperation on Research Infrastructures for Food Security and Greenhouse Gas Observations" (SEACRIFOG; project ID 730995). Financial support for R. Oren was provided by the Erkko Visiting Professor Programme of the Jane and Aatos Erkko 375th Anniversary Fund, through the University of Helsinki. G. Katul acknowledges partial support from the U.S. National Science Foundation (grant numbers NSF-AGS-1644382, NSF-

15 AGS-2028633 and NSF-IOS-175489). The authors thank the ranchers for their help in the setup and instrument maintenance. 


\section{References}

Archibald, S. and Scholes, R. J.: Leaf green-up in a semi-arid African savanna - separating tree and grass responses to environmental cues, Journal of Vegetation Science, 18(4), 583-594, doi:10.1111/j.1654-1103.2007.tb02572.x, 2007.

5 Aurela, M., Lohila, A., Tuovinen, J.-P., Hatakka, J., Riutta, T. and Laurila, T.: Carbon dioxide exchange on a northern boreal fen, Boreal Environment Research, 14, 699-710, 2009.

Baldocchi, D., Falge, E., Gu, L., Olson, R., Hollinger, D., Running, S., Anthoni, P., Bernhofer, C., Davis, K., Evans, R., Fuentes, J., Goldstein, A., Katul, G., Law, B., Lee, X., Malhi, Y., Meyers, T., Munger, W., Oechel, W., U, K. T. P., Pilegaard, K., Schmid, H. P., Valentini, R., Verma, S., Vesala, T., Wilson, K., and Wofsy, S.: FLUXNET: A new tool to study the

10 temporal and spatial variability of ecosystem-scale carbon dioxide, water vapor, and energy flux densities, Bulletin of the American Meteorological Society, 82, 2415-2434, 2001.

Bengtsson, J., Bullock, J. M., Egoh, B., Everson, C., Everson, T., O’Connor, T., O’Farrell, P. J., Smith, H. G. and Lindborg, R.: Grasslands-more important for ecosystem services than you might think, Ecosphere, 10(2), e02582, doi:10.1002/ecs2.2582, 2019.

15 Berkelhammer, M., Noone, D. C., Wong, T. E., Burns, S. P., Knowles, J. F., Kaushik, A., Blanken, P. D. and Williams, M. W.: Convergent approaches to determine an ecosystem's transpiration fraction, Global Biogeochemical Cycles, 30(6), 933951, doi:10.1002/2016GB005392, 2016.

Beukes, J. P., Venter, A. D., Josipovic, M., Zyl, P. G. V., Vakkari, V., Jaars, K., Dunn, M., and Laakso, L.: Chapter 6 Automated Continuous Air Monitoring, in: Monitoring of Air Pollutants, vol. 70, edited by: Forbes, P. B. C., Elsevier, 183-

20 208, https://doi.org/10.1016/bs.coac.2015.09.006, 2015.

Beyer, M., Hamutoko, J. T., Wanke, H., Gaj, M. and Koeniger, P.: Examination of deep root water uptake using anomalies of soil water stable isotopes, depth-controlled isotopic labeling and mixing models, Journal of Hydrology, 566, 122-136, doi:10.1016/j.jhydrol.2018.08.060, 2018.

Bulcock, H. H. and Jewitt, G. P. W.: Modelling canopy and litter interception in commercial forest plantations in South Africa using the Variable Storage Gash model and idealised drying curves, 16, 4693-4705, https://doi.org/10.5194/hess-16-46932012, 2012.

Didan, K.: MOD13Q1 MODIS/Terra Vegetation Indices 16-Day L3 Global 250m SIN Grid V006, NASA EOSDIS Land Processes DAAC, doi:10.5067/MODIS/MOD13Q1.006, 2015.

Do, F. C., Rocheteau, A., Diagne, A. L., Goudiaby, V., Granier, A. and Lhomme, J.-P.: Stable annual pattern of water use by 30 Acacia tortilis in Sahelian Africa, Tree Physiology, 28(1), 95-104, doi:10.1093/treephys/28.1.95, 2008.

Everson, C. S.: The water balance of a first order catchment in the montane grasslands of South Africa, Journal of Hydrology, 241, 110-123, https://doi.org/10.1016/S0022-1694(00)00376-0, 2001.

Foken, T. and Wichura, B.: Tools for quality assessment of surface-based flux measurements, Agricultural and Forest Meteorology, 78, 83-105, https://doi.org/10.1016/0168-1923(95)02248-1, 1996. 
Gash, J. H. C., Lloyd, C. R., and Lachaud, G.: Estimating sparse forest rainfall interception with an analytical model, Journal of Hydrology, 170, 79-86, https://doi.org/10.1016/0022-1694(95)02697-N, 1995.

Godde, C. M., Boone, R. B., Ash, A. J., Waha, K., Sloat, L. L., Thornton, P. K. and Herrero, M.: Global rangeland production systems and livelihoods at threat under climate change and variability, Environ. Res. Lett., 15(4), 044021, doi:10.1088/17489326/ab7395, 2020.

Guan, K., Wood, E. F., Medvigy, D., Kimball, J., Pan, M., Caylor, K. K., Sheffield, J., Xu, X. and Jones, M. O.: Terrestrial hydrological controls on land surface phenology of African savannas and woodlands, Journal of Geophysical Research: Biogeosciences, 119(8), 1652-1669, doi:10.1002/2013JG002572, 2014.

Gwate, O., Mantel, S. K., Gibson, L. A., Munch, Z., and Palmer, A. R.: Exploring dynamics of evapotranspiration in selected land cover classes in a sub-humid grassland: A case study in quaternary catchment S50E, South Africa, Journal of Arid Environments, 157, 66-76, https://doi.org/10.1016/j.jaridenv.2018.05.011, 2018.

Hari, P., Mäkelä, A. and Pohja, T.: Surprising implications of the optimality hypothesis of stomatal regulation gain support in a field test, Functional Plant Biology, 27(1), 77-80, 2000.

Hu, H., Chen, L., Liu, H., Ali Khan, M. Y., Tie, Q., Zhang, X. and Tian, F.: Comparison of the vegetation effect on et 15 partitioning based on eddy covariance method at five different sites of Northern China, Remote Sensing, 10(11), 1755, doi:10.3390/rs10111755, 2018.

Hubert, M. and Vandervieren, E.: An adjusted boxplot for skewed distributions, Computational Statistics \& Data Analysis, 52(12), 5186-5201, doi:10.1016/j.csda.2007.11.008, 2008.

Jaars, K., van Zyl, P. G., Beukes, J. P., Hellén, H., Vakkari, V., Josipovic, M., Venter, A. D., Räsänen, M., Knoetze, L., Cilliers,

20 D. P., Siebert, S. J., Kulmala, M., Rinne, J., Guenther, A., Laakso, L. and Hakola, H.: Measurements of biogenic volatile organic compounds at a grazed savannah grassland agricultural landscape in South Africa, Atmos. Chem. Phys., 16(24), 15665-15688, doi:10.5194/acp-16-15665-2016, 2016.

Jennings, C.M.H.: The hydrology of botswana., PhD thesis., 1974.

Katul, G., Manzoni, S., Palmroth, S. and Oren, R.: A stomatal optimization theory to describe the effects of atmospheric CO2 on leaf photosynthesis and transpiration, Annals of Botany, 105(3), 431-442, 2010.

Katul, G. G., Palmroth, S. and Oren, R.: Leaf stomatal responses to vapour pressure deficit under current and $\mathrm{CO}_{2}$-enriched atmosphere explained by the economics of gas exchange, Plant, Cell \& Environment, 32(8), 968-979, 2009.

Kljun, N., Calanca, P., Rotach, M. W. and Schmid, H. P.: A simple two-dimensional parameterisation for Flux Footprint Prediction (FFP), Geoscientific Model Development, 8(11), 3695-3713, doi:10.5194/gmd-8-3695-2015, 2015.

30 Mamadou, O., Cohard, J. M., Galle, S., Awanou, C. N., Diedhiou, A., Kounouhewa, B. and Peugeot, C.: Energy fluxes and surface characteristics over a cultivated area in Benin: Daily and seasonal dynamics, Hydrology and Earth System Sciences, 18(3), 893-914, doi:10.5194/hess-18-893-2014, 2014. 
Mamadou, O., Galle, S., Cohard, J.-M., Peugeot, C., Kounouhewa, B., Biron, R., Hector, B. and Zannou, A. B.: Dynamics of water vapor and energy exchanges above two contrasting Sudanian climate ecosystems in Northern Benin (West Africa), Journal of Geophysical Research: Atmospheres, 121(19), 11, 269-11, 286, doi:10.1002/2016JD024749, 2016.

Merbold, L., Ardö, J., Arneth, A., Scholes, R. J., Nouvellon, Y., De Grandcourt, A., Archibald, S., Bonnefond, J.-M., Boulain,

5 N., Brueggemann, N. and others: Precipitation as driver of carbon fluxes in 11 African ecosystems, Biogeosciences, 6, 1027$1041,2009$.

Moene, A. F. and Van Dam, J. C.: Transport in the atmosphere-vegetation-soil continuum, Cambridge University Press, 2014. Montaldo, N., Curreli, M., Corona, R., and Oren, R.: Fixed and variable components of evapotranspiration in a Mediterranean wild-olive - grass landscape mosaic, Agricultural and Forest Meteorology, 280, 107769,

10 https://doi.org/10.1016/j.agrformet.2019.107769, 2020.

Moore, C. J.: Frequency response corrections for eddy correlation systems, Boundary-Layer Meteorology, 37(1-2), 17-35, doi:10.1007/BF00122754, 1986.

Nelson, J. A., Carvalhais, N., Cuntz, M., Delpierre, N., Knauer, J., Ogée, J., Migliavacca, M., Reichstein, M. and Jung, M.: Coupling water and carbon fluxes to constrain estimates of transpiration: The TEA algorithm, Journal of Geophysical

15 Research: Biogeosciences, 123(12), 3617-3632, doi:10.1029/2018JG004727, 2018.

Novick, K. A., Oren, R., Stoy, P. C., Siqueira, M. B. S. and Katul, G. G.: Nocturnal evapotranspiration in eddy-covariance records from three co-located ecosystems in the Southeastern U.S.: Implications for annual fluxes, Agricultural and Forest Meteorology, 149(9), 1491-1504, doi:10.1016/j.agrformet.2009.04.005, 2009.

Oishi, A. C., Oren, R., Novick, K. A., Palmroth, S., and Katul, G. G.: Interannual Invariability of Forest Evapotranspiration

20 and Its Consequence to Water Flow Downstream, Ecosystems, 13, 421-436, https://doi.org/10.1007/s10021-010-9328-3, 2010.

Perez-Priego, O., Katul, G., Reichstein, M., El-Madany, T. S., Ahrens, B., Carrara, A., Scanlon, T. M. and Migliavacca, M.: Partitioning eddy covariance water flux components using physiological and micrometeorological approaches, Journal of Geophysical Research: Biogeosciences, 123(10), 3353-3370, doi:10.1029/2018JG004637, 2018.

25 Petäjä, T., Vakkari, V., Pohja, T., Nieminen, T., Laakso, H., Aalto, P. P., Keronen, P., Siivola, E., Kerminen, V.-M., Kulmala, M., and Laakso, L.: Transportable Aerosol Characterization Trailer with Trace Gas Chemistry: Design, Instruments and Verification, Aerosol Air Qual. Res., 13, 421-435, https://doi.org/10.4209/aaqr.2012.08.0207, 2013.

Pollock, M. D., O’Donnell, G., Quinn, P., Dutton, M., Black, A., Wilkinson, M. E., Colli, M., Stagnaro, M., Lanza, L. G., Lewis, E., Kilsby, C. G. and O’Connell, P. E.: Quantifying and mitigating wind-induced undercatch in rainfall measurements, 30 Water Resources Research, 54(6), 3863-3875, doi:10.1029/2017WR022421, 2018.

Priestley, C. H. B. and Taylor, R. J.: On the assessment of surface heat flux and evaporation using large-scale parameters, Monthly Weather Review, 100(2), 81-92, doi:10.1175/1520-0493(1972)100<0081:OTAOSH>2.3.CO;2, 1972. 
Räsänen, M., Aurela, M., Vakkari, V., Beukes, J. P., Tuovinen, J.-P., Van Zyl, P. G., Josipovic, M., Venter, A. D., Jaars, K., Siebert, S. J., Laurila, T., Rinne, J. and Laakso, L.: Carbon balance of a grazed savanna grassland ecosystem in South Africa, Biogeosciences, 14(5), 1039-1054, doi:10.5194/bg-14-1039-2017, 2017.

Räsänen, M., Aurela, M., Vakkari, V., Beukes, P., Tuovinen, J.-P., Siebert, S., Zyl, P. V., Josipovic, M., Laurila, T., Kulmala,

M., Laakso, L., Rinne, J., Oren, R. and Katul, G. G.: Dataset for "The effect of rainfall amount and timing on annual transpiration in grazed savanna grassland," , doi:10.6084/m9.figshare.11322464, 2019.

Reichstein, M., Falge, E., Baldocchi, D., Papale, D., Aubinet, M., Berbigier, P., Bernhofer, C., Buchmann, N., Gilmanov, T., Granier, A., Grünwald, T., Havránková, K., Ilvesniemi, H., Janous, D., Knohl, A., Laurila, T., Lohila, A., Loustau, D., Matteucci, G., Meyers, T., Miglietta, F., Ourcival, J.-M., Pumpanen, J., Rambal, S., Rotenberg, E., Sanz, M., Tenhunen, J.,

10 Seufert, G., Vaccari, F., Vesala, T., Yakir, D. and Valentini, R.: On the separation of net ecosystem exchange into assimilation and ecosystem respiration: Review and improved algorithm, Global Change Biology, 11(9), 1424-1439, doi:10.1111/j.13652486.2005.001002.x, 2005.

Ripley, B., Frole, K. and Gilbert, M.: Differences in drought sensitivities and photosynthetic limitations between co-occurring C3 and C4 (NADP-ME) Panicoid grasses, Annals of Botany, 105(3), 493-503, doi:10.1093/aob/mcp307, 2010.

15 Sankaran, M.: Droughts and the ecological future of tropical savanna vegetation, Journal of Ecology, 107(4), 1531-1549, doi:10.1111/1365-2745.13195, 2019.

Sankaran, M., Ratnam, J. and Hanan, N. P.: Tree-grass coexistence in savannas revisited-insights from an examination of assumptions and mechanisms invoked in existing models, Ecology Letters, 7(6), 480-490, 2004.

Scanlon, T. M., Albertson, J. D., Caylor, K. K. and Williams, C. A.: Determining land surface fractional cover from NDVI

20 and rainfall time series for a savanna ecosystem, Remote Sensing of Environment, 82(2-3), 376-388, 2002.

Scanlon, T. M., Caylor, K. K., Manfreda, S., Levin, S. A. and Rodriguez-Iturbe, I.: Dynamic response of grass cover to rainfall variability: Implications for the function and persistence of savanna ecosystems, Advances in Water Resources, 28(3), 291$302,2005$.

Scholes, R. and Archer, S.: Tree-grass interactions in savannas, Annual Review of Ecology and Systematics, 28(1), 517-544, 1997.

Scholes, R. and Walker, H.: An African Savanna: Synthesis of the Nylsvley study, Cambridge University Press., 1993.

Scott, R. L., Knowles, J. F., Nelson, J. A., Gentine, P., Li, X., Barron-Gafford, G., Bryant, R., and Biederman, J. A.: Water availability impacts on evapotranspiration partitioning, Agricultural and Forest Meteorology, 297, 108251, https://doi.org/10.1016/j.agrformet.2020.108251, 2021.

30 Steenkamp, C. J., Vogel, J. C., Fuls, A., van Rooyen, N. and van Rooyen, M. W.: Age determination of Acacia erioloba trees in the Kalahari, Journal of Arid Environments, 72(4), 302-313, doi:10.1016/j.jaridenv.2007.07.015, 2008.

Stoy, P. C., Mauder, M., Foken, T., Marcolla, B., Boegh, E., Ibrom, A., Arain, M. A., Arneth, A., Aurela, M., Bernhofer, C. and others: A data-driven analysis of energy balance closure across fluxnet research sites: The role of landscape scale heterogeneity, Agricultural and Forest Meteorology, 171, 137-152, 2013. 
Stoy, P. C., El-Madany, T. S., Fisher, J. B., Gentine, P., Gerken, T., Good, S. P., Klosterhalfen, A., Liu, S., Miralles, D. G., Perez-Priego, O., Rigden, A. J., Skaggs, T. H., Wohlfahrt, G., Anderson, R. G., Coenders-Gerrits, A. M. J., Jung, M., Maes, W. H., Mammarella, I., Mauder, M., Migliavacca, M., Nelson, J. A., Poyatos, R., Reichstein, M., Scott, R. L. and Wolf, S.: Reviews and syntheses: Turning the challenges of partitioning ecosystem evaporation and transpiration into opportunities, Biogeosciences, 16(19), 3747-3775, doi:10.5194/bg-16-3747-2019, 2019.

Taylor, S. H., Ripley, B. S., Martin, T., De-Wet, L.-A., Woodward, F. I. and Osborne, C. P.: Physiological advantages of C4 grasses in the field: A comparative experiment demonstrating the importance of drought, Global Change Biology, 20(6), 19922003, doi: $10.1111 / \mathrm{gcb} .12498,2014$.

Tfwala, C. M., van Rensburg, L. D., Bello, Z. A. and Zietsman, P. C.: Transpiration dynamics and water sources for selected

10 indigenous trees under varying soil water content, Agricultural and Forest Meteorology, 275, 296-304, doi:10.1016/j.agrformet.2019.05.030, 2019.

Tor-ngern, P., Oren, R., Oishi, A. C., Uebelherr, J. M., Palmroth, S., Tarvainen, L., Ottosson-Löfvenius, M., Linder, S., Domec, J.-C., and Näsholm, T.: Ecophysiological variation of transpiration of pine forests: synthesis of new and published results, 27 , $118-133,2017$.

15 Urban, M., Berger, C., Mudau, T. E., Heckel, K., Truckenbrodt, J., Onyango Odipo, V., Smit, I. P. J. and Schmullius, C.: Surface moisture and vegetation cover analysis for drought monitoring in the southern Kruger National Park using Sentinel-1, Sentinel-2, and Landsat-8, Remote Sensing, 10(9), 1482, doi:10.3390/rs10091482, 2018.

Volder, A., Briske, D. D. and Tjoelker, M. G.: Climate warming and precipitation redistribution modify tree-grass interactions and tree species establishment in a warm-temperate savanna, Global Change Biology, 19(3), 843-857, 2013.

20 Wang, L., D’Odorico, P., Ringrose, S., Coetzee, S. and Macko, S. A.: Biogeochemistry of Kalahari sands, Journal of Arid Environments, 71(3), 259-279, doi:10.1016/j.jaridenv.2007.03.016, 2007.

Ward, E. J., Oren, R., Kim, H. S., Kim, D., Tor-ngern, P., Ewers, B. E., McCarthy, H. R., Oishi, A. C., Pataki, D. E., Palmroth, S., Phillips, N. G., and Schäfer, K. V. R.: Evapotranspiration and water yield of a pine-broadleaf forest are not altered by longterm atmospheric $\left[\mathrm{CO}_{2}\right]$ enrichment under native or enhanced soil fertility, 24, 4841-4856, https://doi.org/10.1111/gcb.14363, 2018 .

Webb, E. K., Pearman, G. I. and Leuning, R.: Correction of flux measurements for density effects due to heat and water vapour transfer, Quarterly Journal of the Royal Meteorological Society, 106(447), 85-100, 1980.

Wei, Z., Yoshimura, K., Wang, L., Miralles, D. G., Jasechko, S. and Lee, X.: Revisiting the contribution of transpiration to global terrestrial evapotranspiration, Geophysical Research Letters, 44(6), 2792-2801, doi:10.1002/2016GL072235, 2017.

30 Wigley-Coetsee, C. and Staver, A. C.: Grass community responses to drought in an African savanna, African Journal of Range \& Forage Science, 37, 43-52, https://doi.org/10.2989/10220119.2020.1716072, 2020.

Williams, C. A. and Albertson, J. D.: Soil moisture controls on canopy-scale water and carbon fluxes in an African savanna, Water Resources Research, 40(9), 2004. 
Williams, C. A. and Albertson, J. D.: Contrasting short- and long-timescale effects of vegetation dynamics on water and carbon fluxes in water-limited ecosystems: vegetation controls on dryland fluxes, Water Resources Research, 41(6), doi:10.1029/2004WR003750, 2005.

Williams, K. J., Wilsey, B. J., McNaughton, S. J. and Banyikwa, F. F.: Temporally variable rainfall does not limit yields of 5 Serengeti grasses, Oikos, 81(3), 463, doi:10.2307/3546768, 1998.

Wilson, K., Goldstein, A., Falge, E., Aubinet, M., Baldocchi, D., Berbigier, P., Bernhofer, C., Ceulemans, R., Dolman, H., Field, C. and others: Energy balance closure at fluxnet sites, Agricultural and Forest Meteorology, 113(1-4), 223-243, 2002. Wutzler, T., Lucas-Moffat, A., Migliavacca, M., Knauer, J., Sickel, K., Šigut, L., Menzer, O. and Reichstein, M.: Basic and extensible post-processing of eddy covariance flux data with REddyProc, Biogeosciences, 15(16), 5015-5030, 10 doi:https://doi.org/10.5194/bg-15-5015-2018, 2018.

$\mathrm{Xu}, \mathrm{X}$., Medvigy, D. and Rodriguez-Iturbe, I.: Relation between rainfall intensity and savanna tree abundance explained by water use strategies, Proceedings of the National Academy of Sciences, 112(42), 12992-12996, 2015.

Yu, K. and D'Odorico, P.: Hydraulic lift as a determinant of tree-grass coexistence on savannas, New Phytologist, 207(4), 1038-1051, 2015.

15 Zhang, L., Dawes, W. R. and Walker, G. R.: Response of mean annual evapotranspiration to vegetation changes at catchment scale, Water Resources Research, 37(3), 701-708, doi:10.1029/2000WR900325, 2001.

Zhou, S., Yu, B., Zhang, Y., Huang, Y. and Wang, G.: Partitioning evapotranspiration based on the concept of underlying water use efficiency, Water Resources Research, 52(2), 1160-1175, doi:10.1002/2015WR017766, 2016.

Zhou, S., Yu, B., Zhang, Y., Huang, Y. and Wang, G.: Water use efficiency and evapotranspiration partitioning for three

20 typical ecosystems in the Heihe River Basin, northwestern China, Agricultural and Forest Meteorology, 253-254, 261-273, doi:10.1016/j.agrformet.2018.02.002, 2018. 